\title{
Tunable White-Light Emissions of Azapyrene Derivatives with Cucurbit[n]uril Hosts in Aqueous Solution
}

Guangtan Fan, ${ }^{a}$ Xiang Yu, ${ }^{a}$ Xie Han, ${ }^{a, b}$ Zhiyong Zhao, ${ }^{a, b}$ and Simin Liu*a,b

a The State Key Laboratory of Refractories and Metallurgy, School of Chemistry and Chemical Engineering, Wuhan University of Science and Technology, Wuhan 430081, China.

b Institute of Advanced Materials and Nanotechnology, Wuhan University of Science and Technology, Wuhan 430081, China.

*E-mail: liusimin@wust.edu.cn.

\begin{tabular}{|c|c|c|}
\hline Table of Contents & & Page \\
\hline General experimental section & & S2 \\
\hline Synthesis of G2-G4 guest molecules & ....... & S3-S4 \\
\hline $\begin{array}{l}\text { Binding data (ESI-MS, UV-Vis and fluorescence } \\
\text { titration) of } \mathbf{G} 1 \text { with } C B[10]\end{array}$ & 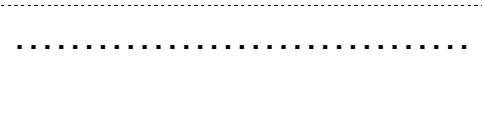 & S5-S6 \\
\hline NMR spectra of $\mathbf{G} 2$ with addition of CB[8, 10] & $\ldots \ldots \ldots \ldots \ldots \ldots \ldots \ldots \ldots$ & S6-S8 \\
\hline ESI-MS of complexation of G2-G4 with CB[8, 10] & 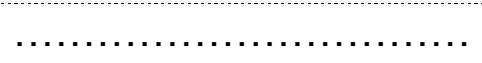 & S8-S9 \\
\hline NMR spectra of G3-G4 with addition of CB[8, 10] & $\ldots \ldots$ & S9-S12 \\
\hline $\begin{array}{l}\text { UV-Vis and fluorescence spectra of G2-G4 with } \\
\text { addition of } C B[8,10]\end{array}$ & 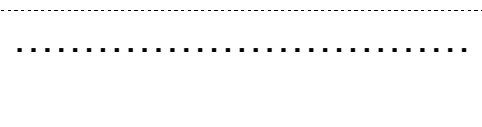 & S13-S15 \\
\hline $\begin{array}{l}\text { Steady-state spectral data of } \mathbf{G} 2-\mathbf{G} 4 \text { and their } \\
\text { complexes with } \mathrm{CB}[8,10] \text { in water }\end{array}$ & & S15-S16 \\
\hline${ }^{1} \mathrm{H}$ and ${ }^{13} \mathrm{C}$ NMR spectra of new compounds & 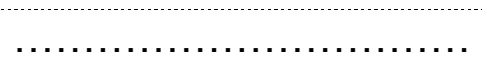 & S17-S23 \\
\hline References & & S23 \\
\hline
\end{tabular}




\section{General Experimental Section.}

$\mathrm{CB}[8]$ and $\mathrm{CB}[10]$ were prepared by the corresponding literature procedures. ${ }^{1}$ Other compounds used in this study were purchased from commercial suppliers and were used without further purification. NMR spectra $\left({ }^{1} \mathrm{H},{ }^{13} \mathrm{C}, \mathrm{COSY}, \mathrm{ROSY}\right)$ were collected on Agilent $600 \mathrm{MHz}$ DD2 or Bruker AVIII-600MHz spectrometers. Mass spectrometry was performed using a Bruker FT-ICR Apex IV qQ equipped 12T super conducting magnet. UV/Vis were performed on a SHIMADZU UV-3600 instrument with $1 \mathrm{~cm}$ pathlength cells at $298 \mathrm{~K}$. Fluorescence spectra were measured on a PerkinEImer LS-55 machine. Time-Correlated Single Photon Counting (TCSPC) was recorded using a FS5 Spectrofluorometer, Edinburgh FLS1000. A TCSPC laser (360 $\mathrm{nm}$ ) was used for fluorescence lifetime measurements at peak emission wavelength for guest molecules and their complexes. A Suprasil Quartz (QS) cuvette with $1 \mathrm{~cm}$ path length was used for all measurements. The data was fit with the exponential reconvolution function and the non-linear least square method. The absolute fluorescence quantum yield was determined by using a Hamamatsu C9920-02G Instruments Integrating Sphere Module (SC-30) on the FS5 spectrofluorometer. Fluorescence spectra analysis software Fluoracle and Quantum Yield Wizard were used to quantum yields. The $1.5 \mathrm{~mL}$ Suprasil Quartz (QS) cuvette with $1 \mathrm{~cm}$ path length was used for all measurements at $298 \mathrm{~K}$. Fluorescence quantum yield measurements were done for $1 \mathrm{~mL}$ aqueous solutions of G2-G4 with $\mathrm{CB}[8]$ and $\mathrm{CB}[10]$ with an optical density in the range of 0.06-0.1. 


\section{Synthesis and characterization.}

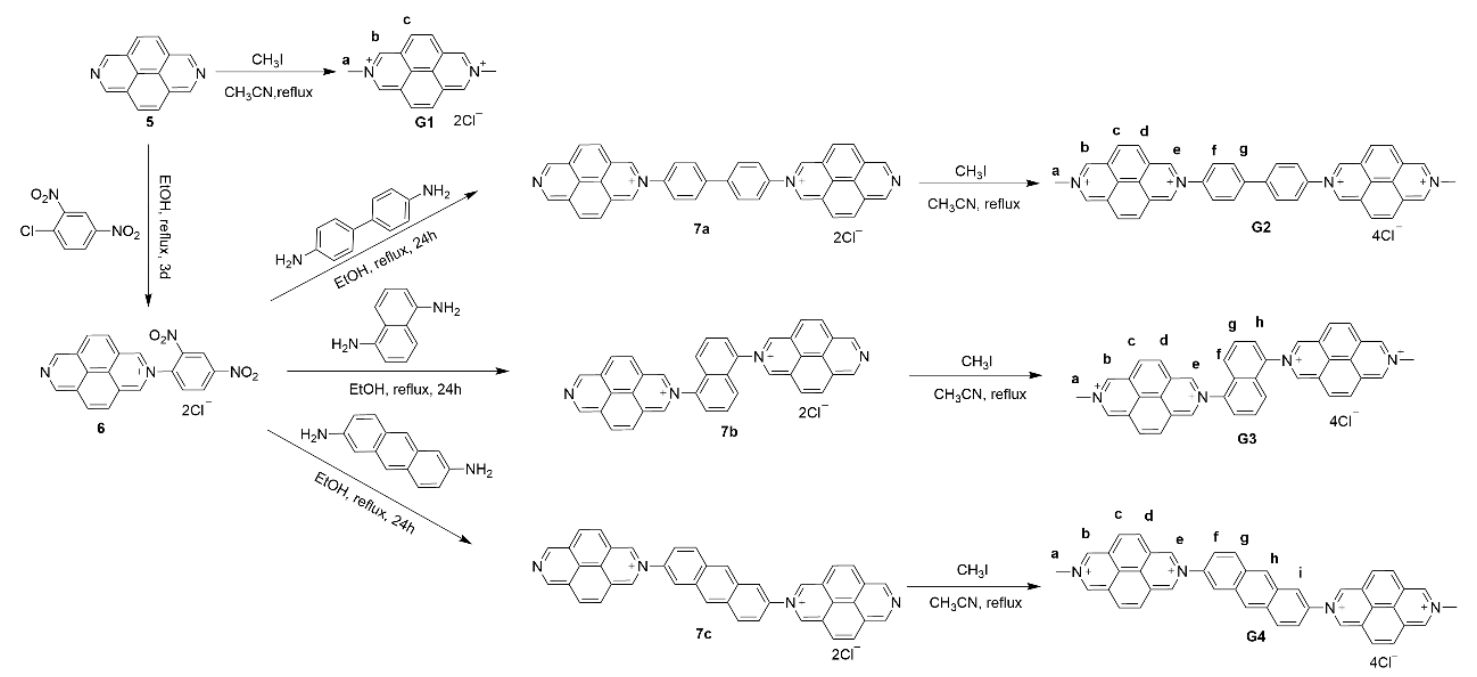

Scheme S1. Synthesis route of azapyrene derivatized G2-G4.

Synthesis of $\mathbf{G 1}$ were adapted and modified from previously reported procedures. ${ }^{2}$

5-(benzo[Imn][3, 8]phenanthrolin-2-ium-2-yl)-2,4-dinitrobenzen-1-ide(6)

Compound 5 (2 g, $10 \mathrm{mmol})$ and 1-chloro-2,4-dinitrobenzene $(2 \mathrm{~g}, 10 \mathrm{mmol})$ were added in $\mathrm{EtOH}(100 \mathrm{ml})$, the mixture was heated in oil bath to refluxed for $72 \mathrm{~h}$. After evaporating solvent under reduced pressure, the solid was re-dissolved in $\mathrm{MeOH}(10 \mathrm{~mL})$ and was added dropwise into diethyl ether $(400 \mathrm{~mL})$ to precipitate products. Decant of the supernatant after centrifuging by $8000 \mathrm{rpm}$ for $3 \mathrm{mins}$ and repeat above $\mathrm{MeOH}-\mathrm{Ether}$ step for another two times. Drying in vacuum oven gave yellow solid $(3.4 \mathrm{~g}, 93 \%)$. ${ }^{1} \mathrm{H} \mathrm{NMR}(600 \mathrm{MHz}$, DMSO-d 6 ) $\delta(\mathrm{ppm}): 10.47(\mathrm{~s}, 2 \mathrm{H}), 10.06(\mathrm{~s}, 2 \mathrm{H}), 9.25(\mathrm{~d}, J=2.6 \mathrm{~Hz}, 1 \mathrm{H}), 9.10(\mathrm{dd}, J=8.6,2.6 \mathrm{~Hz}, 1 \mathrm{H}), 8.94$ $(\mathrm{d}, J=9.0 \mathrm{~Hz}, 2 \mathrm{H}), 8.72(\mathrm{~d}, J=9.0 \mathrm{~Hz}, 2 \mathrm{H}), 8.57(\mathrm{~d}, J=8.6 \mathrm{~Hz}, 1 \mathrm{H})$.

\section{2,2'-([1,1'-biphenyl]-4,4'-diyl)bis(benzo[Imn][3, 8]phenanthrolin-2-ium (7a)}

To a solution of EtOH $(20 \mathrm{ml})$ was added compound 6 (455 mg, $1.05 \mathrm{mmol}$ ) and benzidine (92 mg, $0.5 \mathrm{mmol})$, the mixture was heated in oil bath to refluxed for $24 \mathrm{~h}$. Thereafter, the reaction mixture was cooled to room temperature and concentrated. The residue was dissolved in $\mathrm{MeOH}: \mathrm{H}_{2} \mathrm{O}(1: 1,20 \mathrm{ml})$, added excess $\mathrm{NH}_{4} \mathrm{PF}_{6}$ and the filter cake was filtered, purified by silica gel column chromatograph (DCM: $\mathrm{CH}_{3} \mathrm{CN}$ (saturated $\left.\mathrm{NH}_{4} \mathrm{PF}_{6}\right)=1: 1$ ), the solid was washed by $\mathrm{H}_{2} \mathrm{O}$ for three times in order to wash off excess $\mathrm{NH}_{4} \mathrm{PF}_{6}$, dried in vacuum at $60{ }^{\circ} \mathrm{C}$ to give brown solid $7 \mathrm{a}(56 \mathrm{mg}, 20 \%) .{ }^{1} \mathrm{H}$ NMR $\left(600 \mathrm{MHz}, \mathrm{DMSO}-\mathrm{d}_{6}\right) \delta(\mathrm{ppm}): 10.52(\mathrm{~s}, 4 \mathrm{H})$, $10.02(\mathrm{~s}, 4 \mathrm{H}), 8.91(\mathrm{~d}, J=9.0 \mathrm{~Hz}, 4 \mathrm{H}), 8.76(\mathrm{~d}, J=9.0 \mathrm{~Hz}, 4 \mathrm{H}), 8.43(\mathrm{~d}, J=8.4 \mathrm{~Hz}, 4 \mathrm{H}), 8.36(\mathrm{~d}, J=8.1 \mathrm{~Hz}$, $4 \mathrm{H}) .{ }^{13} \mathrm{C}$ NMR $\left(151 \mathrm{MHz}, \mathrm{CD}_{3} \mathrm{CN}\right) \delta 146.0,143.9,142.0,139.1,129.7,129.4,128.5,127.1,127.0,126.1$, 125.2. HRMS (ESI): $m / z$ [M-2PF $\left.{ }_{6}^{-}\right]^{2+}$ calcd. for $\mathrm{C}_{40} \mathrm{H}_{24} \mathrm{~N}_{4}{ }^{2+}: 280.0995$, found: 280.0995 .

\section{2,2'-(naphthalene-1,5-diyl)bis(benzo[Imn][3,8]phenanthrolin-2-ium) (7b)}

To a solution of EtOH $(20 \mathrm{ml})$ was added compound $6(813 \mathrm{mg}, 2.0 \mathrm{mmol})$ and Naphthalene-1,5-diamine (79 $\mathrm{mg}, 0.5 \mathrm{mmol}$ ), the mixture was heated in oil bath to refluxed for $24 \mathrm{~h}$. Thereafter, the reaction mixture was cooled to room temperature and concentrated. The residue was dissolved in $\mathrm{MeOH}: \mathrm{H}_{2} \mathrm{O}(1: 1,20 \mathrm{ml})$, added excess $\mathrm{NH}_{4} \mathrm{PF}_{6}$ and the filter cake was filtered, purified by silica gel column chromatograph (DCM: $\mathrm{CH}_{3} \mathrm{CN}$ (saturated $\mathrm{NH}_{4} \mathrm{PF}_{6}$ ) =1:1), the solid was washed by $\mathrm{H}_{2} \mathrm{O}$ for three times in order to wash off excess $\mathrm{NH}_{4} \mathrm{PF}_{6}$, 
dried in vacuum at $60{ }^{\circ} \mathrm{C}$ to give brownish black solid (78 mg, 28\%). ${ }^{1} \mathrm{H} \mathrm{NMR}\left(600 \mathrm{MHz}, \mathrm{CD}_{3} \mathrm{CN}\right) \delta(\mathrm{ppm})$ : $10.20(\mathrm{~s}, 4 \mathrm{H}), 9.95$ (d, $J=0.7 \mathrm{~Hz}, 4 \mathrm{H}), 8.98(\mathrm{~d}, J=0.9 \mathrm{~Hz}, 8 \mathrm{H}), 8.27(\mathrm{dd}, J=7.2,0.9 \mathrm{~Hz}, 2 \mathrm{H}), 8.01$ (dd, $J=$ 8.7, 7.3 Hz, 2H), $7.93-7.90(\mathrm{~m}, 2 \mathrm{H}), 4.94(\mathrm{~s}, 6 \mathrm{H}) .{ }^{13} \mathrm{C}$ NMR $\left(151 \mathrm{MHz}, \mathrm{CD}_{3} \mathrm{CN}\right) \delta 148.8,140.3,140.0,132.0$, 128.5, 127.4, 126.1, 125.7. HRMS (ESI): $\mathrm{m} / \mathrm{z}\left[\mathrm{M}-2 \mathrm{PF}_{6}{ }^{2+}\right]^{2+}$ calcd. for $\mathrm{C}_{38} \mathrm{H}_{22} \mathrm{~N}_{4}{ }^{2+}: 267.0917$, found: 267.0916 .

7-(6-(benzo[Imn][3, 8]phenanthrolin-2-ium-2-yl)anthracen-2yl)benzo[Imn][3,8] phenanthrolin-7-ium-4-ide (7c) To a solution of EtOH $(20 \mathrm{ml})$ was added compound $6(813 \mathrm{mg}, 2.0 \mathrm{mmol})$ and anthracene-2,6-diamine (104 $\mathrm{mg}, 0.5 \mathrm{mmol}$ ), the mixture was heated in oil bath to refluxed for $24 \mathrm{~h}$. Thereafter, the reaction mixture was cooled to room temperature and concentrated. The residue was dissolved in $\mathrm{MeOH}: \mathrm{H}_{2} \mathrm{O}(1: 1,20 \mathrm{ml})$, added excess $\mathrm{NH}_{4} \mathrm{PF}_{6}$ and the filter cake was filtered, purified by silica gel column chromatograph (DCM: $\mathrm{CH}_{3} \mathrm{CN}$ (saturated $\mathrm{NH}_{4} \mathrm{PF}_{6}$ ) $=1: 1$ ), the solid was washed by $\mathrm{H}_{2} \mathrm{O}$ for three times in order to wash off excess $\mathrm{NH}_{4} \mathrm{PF}_{6}$, dried in vacuum at $60{ }^{\circ} \mathrm{C}$ to give brownish solid (64 mg, 21\%). ${ }^{1} \mathrm{H}$ NMR $\left(600 \mathrm{MHz}, \mathrm{CD}_{3} \mathrm{CN}\right) \delta(\mathrm{ppm}): 10.34$ (s, 4H), $9.92(\mathrm{~s}, 4 \mathrm{H}), 9.19(\mathrm{~s}, 2 \mathrm{H}), 9.00(\mathrm{~s}, 4 \mathrm{H}), 8.96(\mathrm{~d}, J=9.0 \mathrm{~Hz}, 4 \mathrm{H}), 8.91(\mathrm{~d}, J=2.5 \mathrm{~Hz}, 2 \mathrm{H}), 8.73(\mathrm{~d}, J=9.0$ $\mathrm{Hz}, 2 \mathrm{H}), 8.21$ (dd, $J=9.0,2.4 \mathrm{~Hz}, 2 \mathrm{H}), 4.93(\mathrm{~s}, 6 \mathrm{H}) .{ }^{13} \mathrm{C} \mathrm{NMR}\left(151 \mathrm{MHz}, \mathrm{CD}_{3} \mathrm{CN}\right) \delta 148.0,138.5,132.1$, 131.8, 129.3, 129.2, 126.0, 124.2, 122.6. HRMS (ESI): $\mathrm{m} / \mathrm{z}\left[\mathrm{M}-2 \mathrm{PF}_{6}{ }^{2}\right]^{2+}$ calcd. for $\mathrm{C}_{42} \mathrm{H}_{24} \mathrm{~N}_{4}{ }^{2+}: 292.0995$, found: 292.0995.

2-methyl-7-(4'-(7-methylbenzo[Imn][3,8]phenanthrolin-2,7-diium-2-yl)-[1,1'-biphenyl]-4-yl)benzo[Imn][3, 8]phe nanthroline-2,7-diium-4-ide (G2)

To a solution of $\mathrm{CH}_{3} \mathrm{CN}(10 \mathrm{ml})$ was added compound $7 \mathrm{a}(56 \mathrm{mg}, 0.1 \mathrm{mmol})$, then methyl iodide $(1 \mathrm{ml})$ was added, the mixture was heated in oil bath to refluxed for $24 \mathrm{~h}$. The reaction mixture was cooled to room temperature and concentrated. The residue was dissolved in $\mathrm{MeOH}: \mathrm{H}_{2} \mathrm{O}(1: 1,20 \mathrm{ml})$, added excess $\mathrm{NH}_{4} \mathrm{PF}_{6}$ and the filter cake was filtered, purified by silica gel column chromatograph $\left(\mathrm{CH}_{3} \mathrm{CN}: \mathrm{H}_{2} \mathrm{O}\right.$ (saturated $\left.\mathrm{NH}_{4} \mathrm{PF}_{6}\right)=20: 1$ ) to give brown solid, the solid was washed by $\mathrm{H}_{2} \mathrm{O}$ for three times in order to wash off excess $\mathrm{NH}_{4} \mathrm{PF}_{6}$, dried in vacuum at $60{ }^{\circ} \mathrm{C}$, the solid was dissolved in acetone $(10 \mathrm{ml})$, and excess $\mathrm{Bu}_{4} \mathrm{~N}^{+} \mathrm{Cl}^{-}$was added, the filter cake was centrifuged, washed by acetone for three times and dried in vacuum at $60{ }^{\circ} \mathrm{C}$ to give brown solid G2 (42 mg, 71\%). ${ }^{1} \mathrm{H}$ NMR $\left(600 \mathrm{MHz}, \mathrm{D}_{2} \mathrm{O}\right) \delta(\mathrm{ppm}): 10.49(\mathrm{~s}, 4 \mathrm{H}), 10.14(\mathrm{~s}, 4 \mathrm{H}), 9.00$ (q, J $=8.9 \mathrm{~Hz}, 8 \mathrm{H}), 8.34(\mathrm{~d}, J=7.8 \mathrm{~Hz}, 4 \mathrm{H}), 8.26(\mathrm{~d}, J=8.1 \mathrm{~Hz}, 4 \mathrm{H}), 5.04(\mathrm{~s}, 6 \mathrm{H}) .{ }^{13} \mathrm{C} N M R\left(151 \mathrm{MHz}, \mathrm{D}_{2} \mathrm{O}\right) \delta$ (ppm): 143.4, 142.2, 142.1, 141.1, 130.3, 130.1, 129.7, 129.7, 129.7, 127.2, 126.7, 125.7, 50.0. HRMS (ESI): $\mathrm{m} / \mathrm{z}\left[\mathrm{M}-4 \mathrm{Cl}^{4+}{ }^{4+}\right.$ calcd. for $\mathrm{C}_{42} \mathrm{H}_{30} \mathrm{~N}_{4}{ }^{4+}: 147.5612$, found: 147.5612 .

Products G3, G4 were synthesized via the same procedures as G2.

7,7'-(naphthalene-1,5-diyl)bis(2-methylbenzo[Imn][3,8]phenanthroline-2,7-diium) (G3)

Brownish black solid (56 mg, 83\%). ${ }^{1} \mathrm{H}$ NMR (600 MHz, $\left.\mathrm{D}_{2} \mathrm{O}\right) \delta(\mathrm{ppm}): 10.54$ (s, 4H), 10.20 (s, 4H), 9.03 (q, J $=9.1 \mathrm{~Hz}, 8 \mathrm{H}), 8.32(\mathrm{~d}, J=7.2 \mathrm{~Hz}, 2 \mathrm{H}), 8.01$ (dd, $J=8.7,7.4 \mathrm{~Hz}, 2 \mathrm{H}), 7.87(\mathrm{~d}, J=8.8 \mathrm{~Hz}, 2 \mathrm{H}), 5.07$ (s, 6H).

${ }^{13} \mathrm{C}$ NMR $\left(151 \mathrm{MHz}, \mathrm{D}_{2} \mathrm{O}\right) \delta(\mathrm{ppm}): 142.9,142.5,139.9,130.8,130.1,130.0,128.6,128.1,127.9,127.2$, 126.6, 125.1, 50.1. HRMS (ESI): $\mathrm{m} / \mathrm{z}[\mathrm{M}-4 \mathrm{Cl}]^{4+}$ calcd. for $\mathrm{C}_{40} \mathrm{H}_{28} \mathrm{~N}_{4}{ }^{4+}: 141.0573$, found: 141.0574 .

7,7'-(anthracene-2,6-diyl)bis(2-methylbenzo[Imn][3,8]phenanthroline-2,7-diium) (G4)

Brownish solid (32 mg, 45\%). ${ }^{1} \mathrm{H}$ NMR (600 MHz, $\left.\mathrm{D}_{2} \mathrm{O}\right) \delta(\mathrm{ppm}): 10.60(\mathrm{~s}, 4 \mathrm{H}), 10.15(\mathrm{~s}, 4 \mathrm{H}), 9.22-9.18(\mathrm{~m}$, 2H), $9.04(\mathrm{~d}, J=9.0 \mathrm{~Hz}, 4 \mathrm{H}), 9.00(\mathrm{~d}, J=8.8 \mathrm{~Hz}, 4 \mathrm{H}), 8.96(\mathrm{~s}, 2 \mathrm{H}), 8.72(\mathrm{~d}, J=9.0 \mathrm{~Hz}, 2 \mathrm{H}), 8.23(\mathrm{~d}, J=8.9$ $\mathrm{Hz}, 2 \mathrm{H}), 5.04(\mathrm{~s}, 6 \mathrm{H}) .{ }^{13} \mathrm{C} N M R\left(151 \mathrm{MHz}, \mathrm{D}_{2} \mathrm{O}\right) \delta(\mathrm{ppm}): 142.2,141.5,141.3,132.3,132.0,131.7,130.3$, 130.1 , 129.8, 129.7, 129.4, 127.2, 126.7, 126.1, 122.0, 50.0. HRMS (ESI): $\mathrm{m} / \mathrm{z}\left[\mathrm{M}-4 \mathrm{Cl}^{4+}\right.$ calcd. for $\mathrm{C}_{44} \mathrm{H}_{30} \mathrm{~N}_{4}{ }^{4+}: 153.5612$, found: 153.5613. 


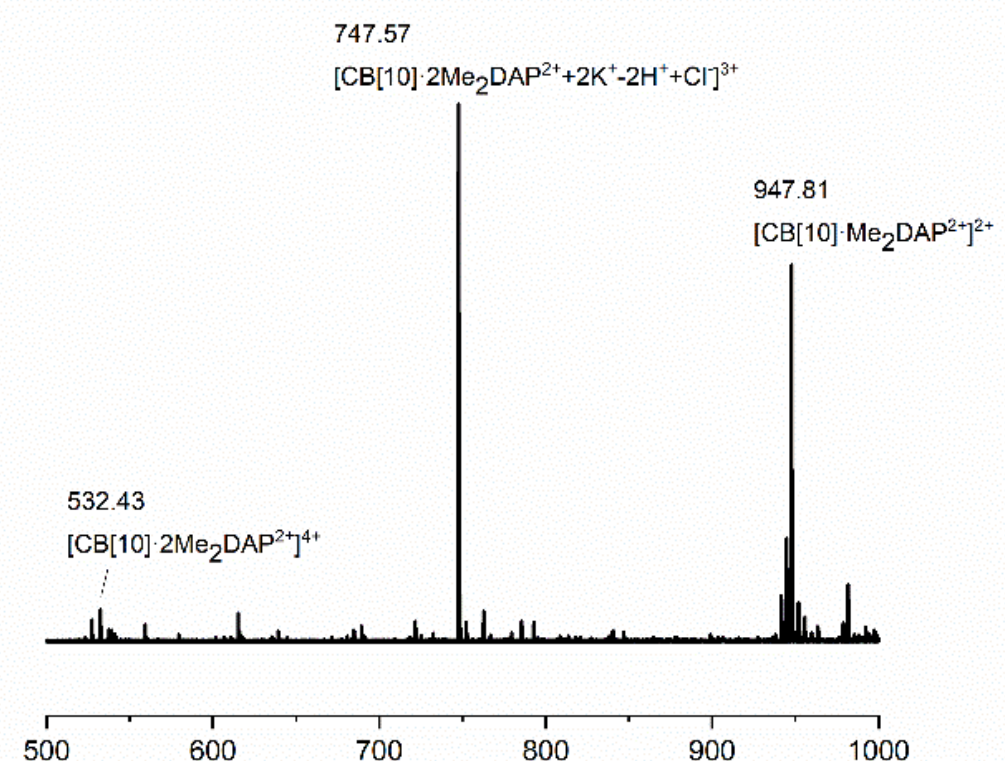

Figure S1. ESI-MS spectrum of $\mathbf{G 1}\left(\mathrm{Me}_{2} \mathrm{DAP}{ }^{2+}\right)$ with $\mathrm{CB}[10]$.

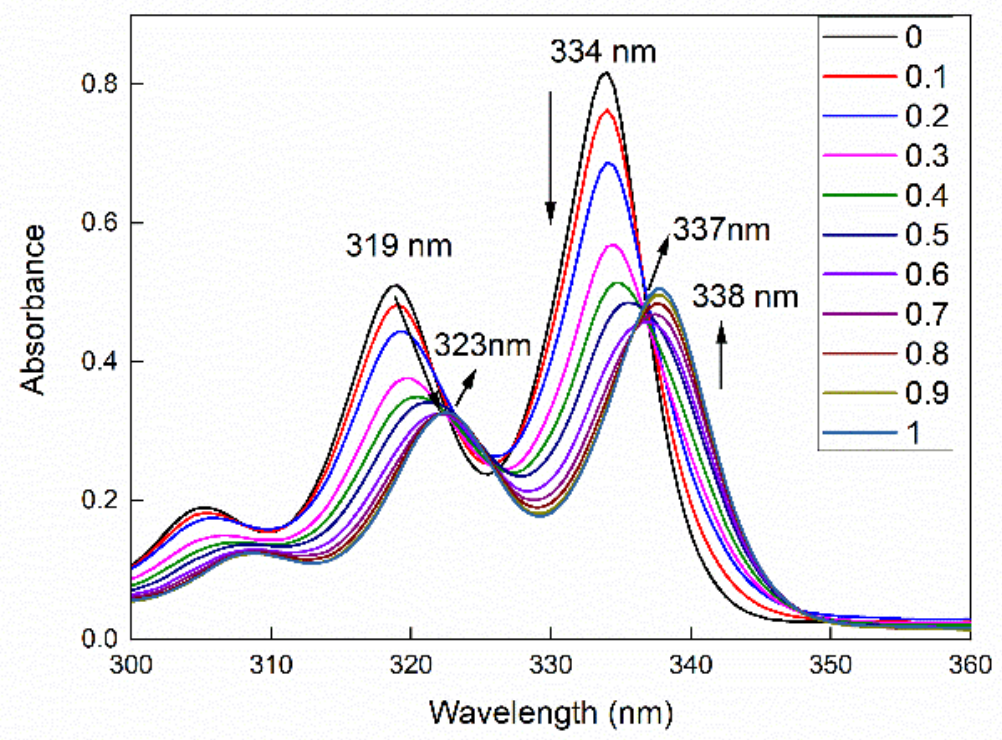

Figure S2. UV-Vis absorption spectra of $\mathbf{G 1}(25 \mu \mathrm{M})$ with addition of different equivalences of CB[10]. 


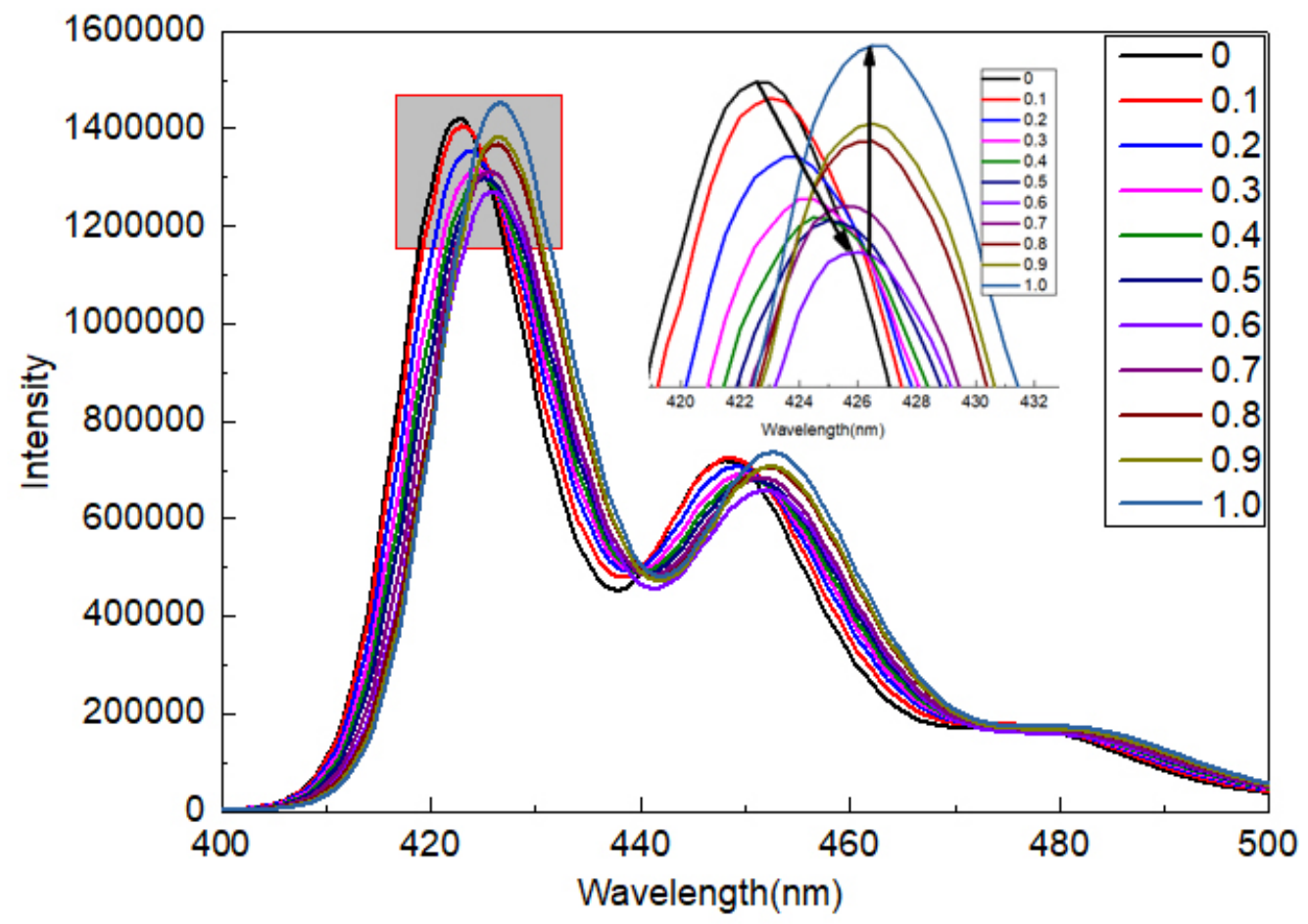

Figure S3. Fluorescence spectra $\left(\lambda_{\mathrm{ex}}=338 \mathrm{~nm}\right.$; slit width: $\left.e_{\mathrm{x}}=5 \mathrm{~nm}, \mathrm{e}_{\mathrm{m}}=5 \mathrm{~nm}\right)$ of $\mathbf{G 1}(10 \mu \mathrm{M})$ with addition of different equivalences of $\mathrm{CB}[10]$ in water.

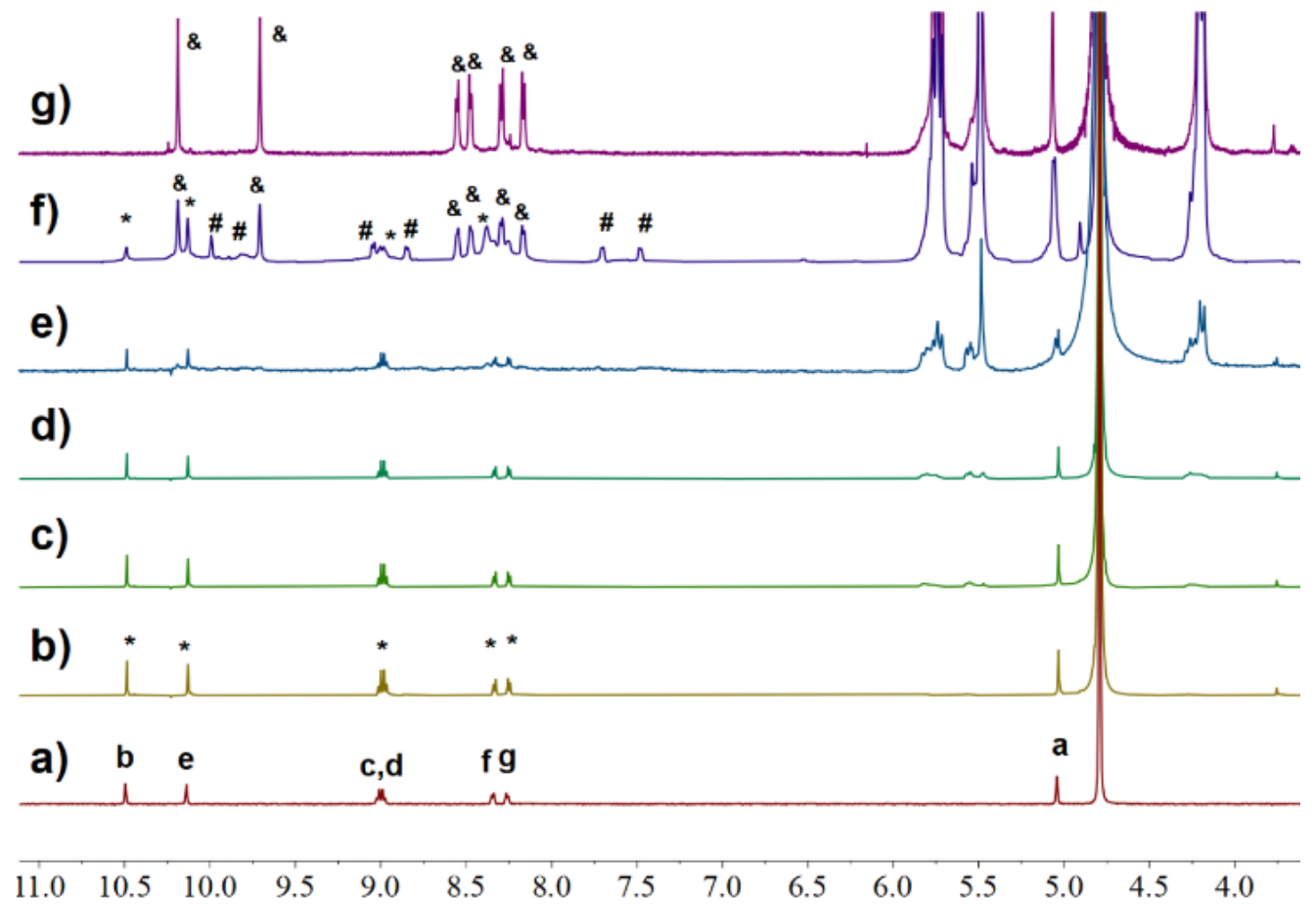

Figure S4. ${ }^{1} \mathrm{H}$ NMR spectra recorded $\left(600 \mathrm{MHz}, \mathrm{D}_{2} \mathrm{O}, 298 \mathrm{~K}\right)$ for compound $\mathbf{G} 2(1.0 \mathrm{mM})$ with addition of different equivalences of $\mathrm{CB}[8]$ (a: 0, b: 0.2, c: 0.4, d: 0.6, e: 0.8, f: 1.0, g: 2.0) (resonances of free $\mathbf{G 2}$ are marked with '*'; resonances of $\mathrm{CB}[8] \cdot \mathrm{G} 2$ are marked with '\#', resonances of $\mathrm{CB}[8]_{2} \cdot \mathbf{G} 2$ are marked with ' $\&$ '). 


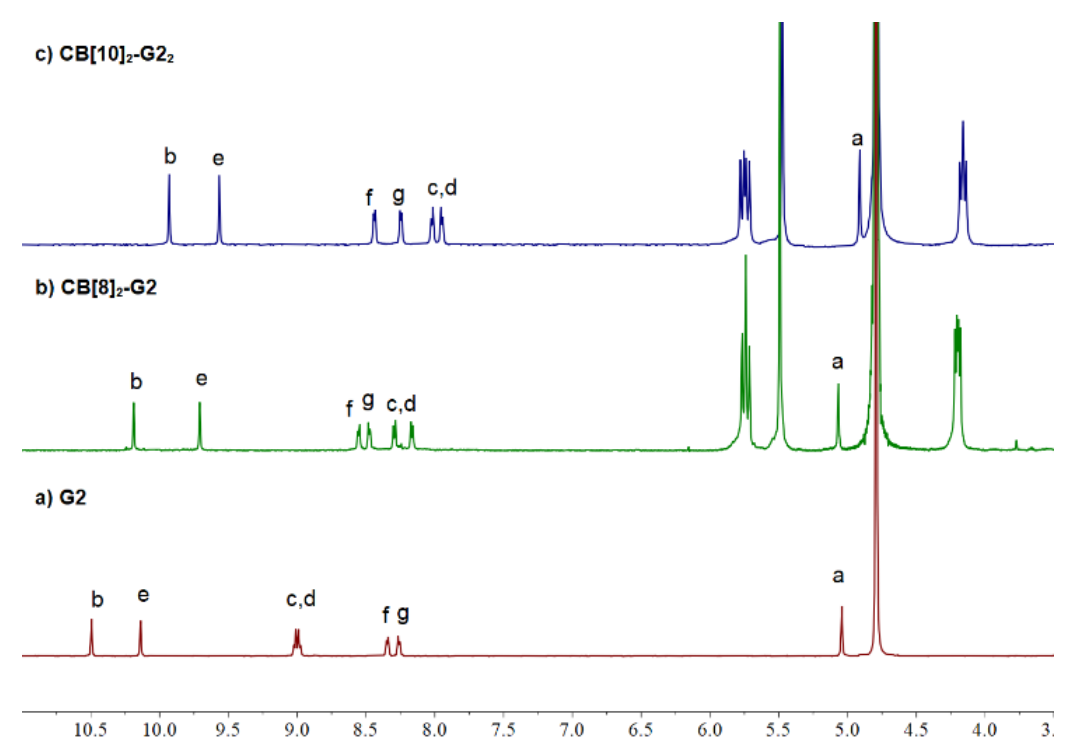

Figure S5. ${ }^{1} \mathrm{H}$ NMR spectra recorded $\left(600 \mathrm{MHz}, \mathrm{D}_{2} \mathrm{O}, 298 \mathrm{~K}\right)$ for $\mathbf{G} 2(1.0 \mathrm{mM})(\mathrm{a}), \mathrm{CB}[8]_{2} \cdot \mathbf{G} 2(\mathrm{~b})$ and $\mathrm{CB}[10]_{2} \cdot \mathbf{G} 2_{2}(\mathrm{c})$.

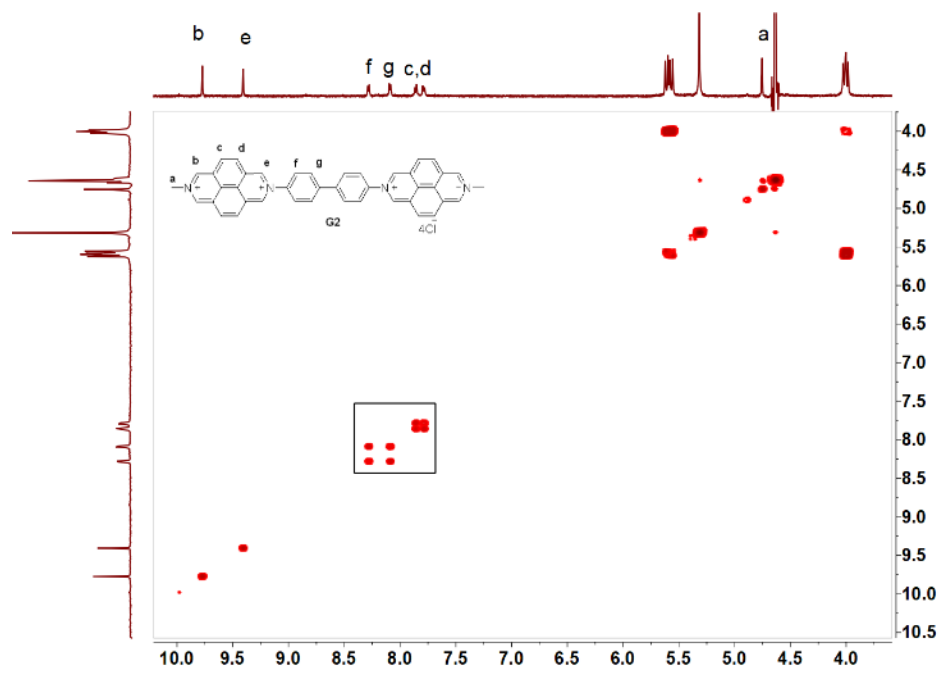

Figure S6. COSY NMR spectrum recorded $\left(600 \mathrm{MHz}, \mathrm{D}_{2} \mathrm{O}, 298 \mathrm{~K}\right)$ for $\mathrm{CB}[10]_{2} \cdot \mathbf{G 2}_{2}([\mathbf{G} 2]=1.0 \mathrm{mM})$.

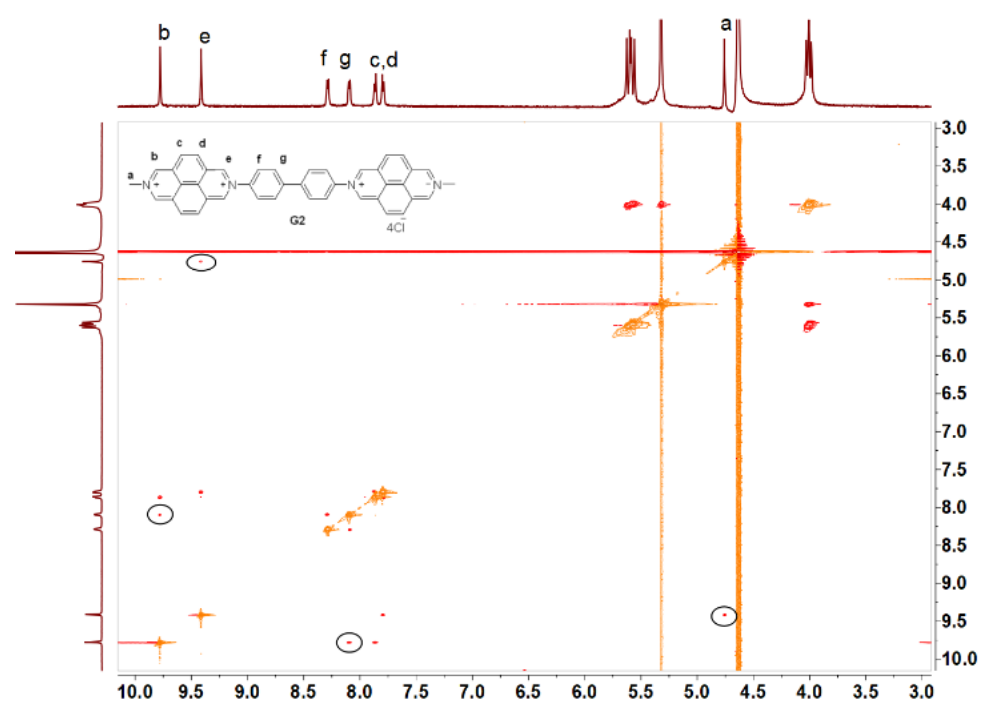

Figure S7. ROESY NMR spectrum recorded $\left(600 \mathrm{MHz}, \mathrm{D}_{2} \mathrm{O}, 298 \mathrm{~K}\right)$ for $\mathrm{CB}[10]_{2} \cdot \mathbf{G} \mathbf{2}_{2}([\mathbf{G} 2]=1.0 \mathrm{mM})$. 

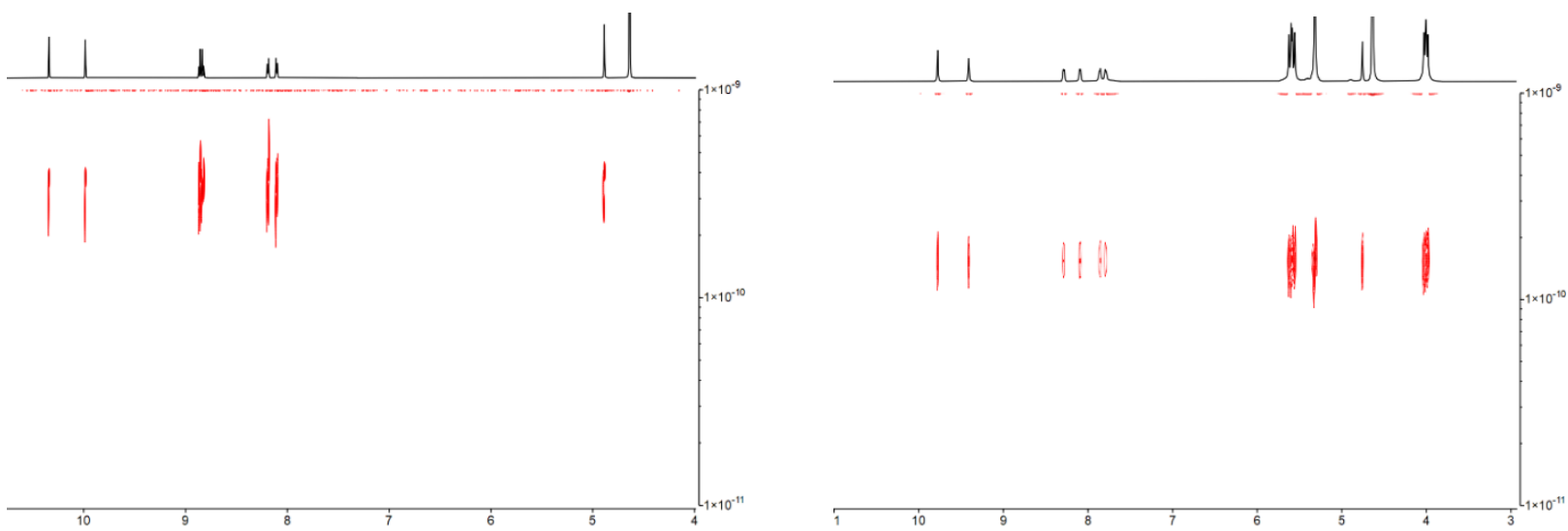

Figure S8. DOSY NMR spectra recorded $\left(600 \mathrm{MHz}, \mathrm{D}_{2} \mathrm{O}, 298 \mathrm{~K}\right)$ for free $\mathbf{G} 2\left(D=3.30 \times 10^{-10} \mathrm{~m}^{2} / \mathrm{s}\right)$ and $\mathrm{CB}[10]_{2} \cdot \mathbf{G 2}_{2}\left(D=1.53 \times 10^{-10} \mathrm{~m}^{2} / \mathrm{s}\right)$.

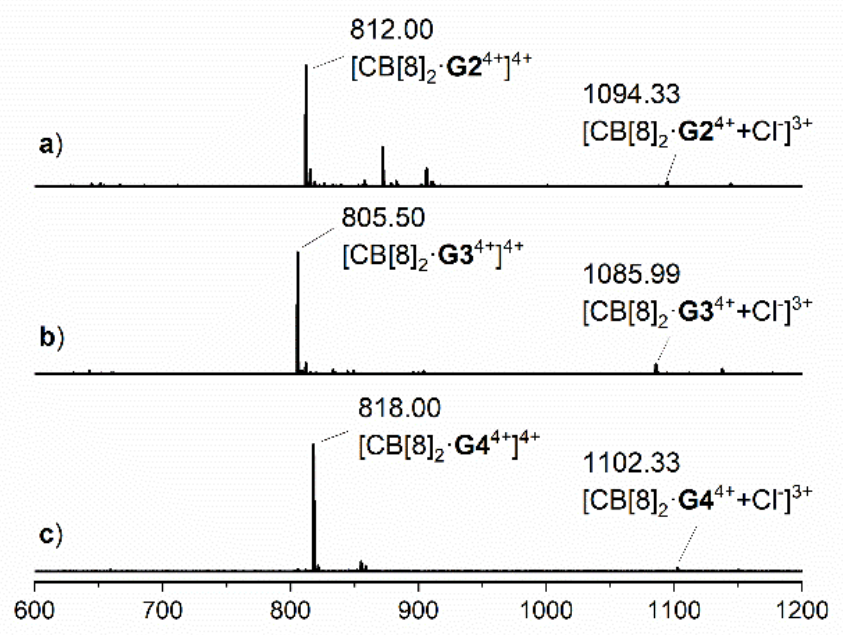

Figure S9. ESI-MS spectra of compound G2 (a), G3 (b), G4 (c) with 2 equiv. of CB[8]. The ion at $\mathrm{m} / \mathrm{z}=$ 805.50 which corresponding to the $2: 1$ complex $\left(\left[2 \mathrm{CB}[8]+\mathbf{G}^{4+}\right]^{4+}=805.25\right)$ was observed $(b)$; the ion at $m / z=818.00$ which corresponding to the $2: 1$ complex $\left(\left[2 \mathrm{CB}[8]+\mathbf{G} 4^{4+}\right]^{4+}=817.76\right)$ was observed (c).

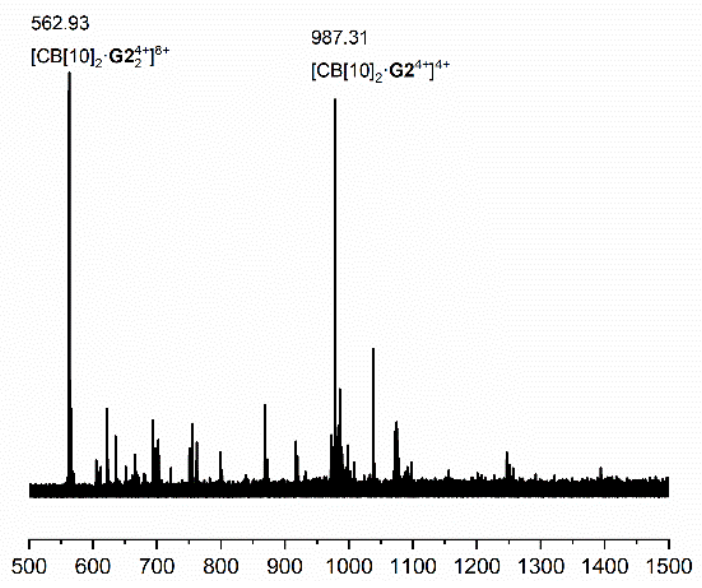

Figure S10. ESI-MS spectrum of compound $\mathbf{G 2}$ with 1.0 equiv. of CB[10]. 


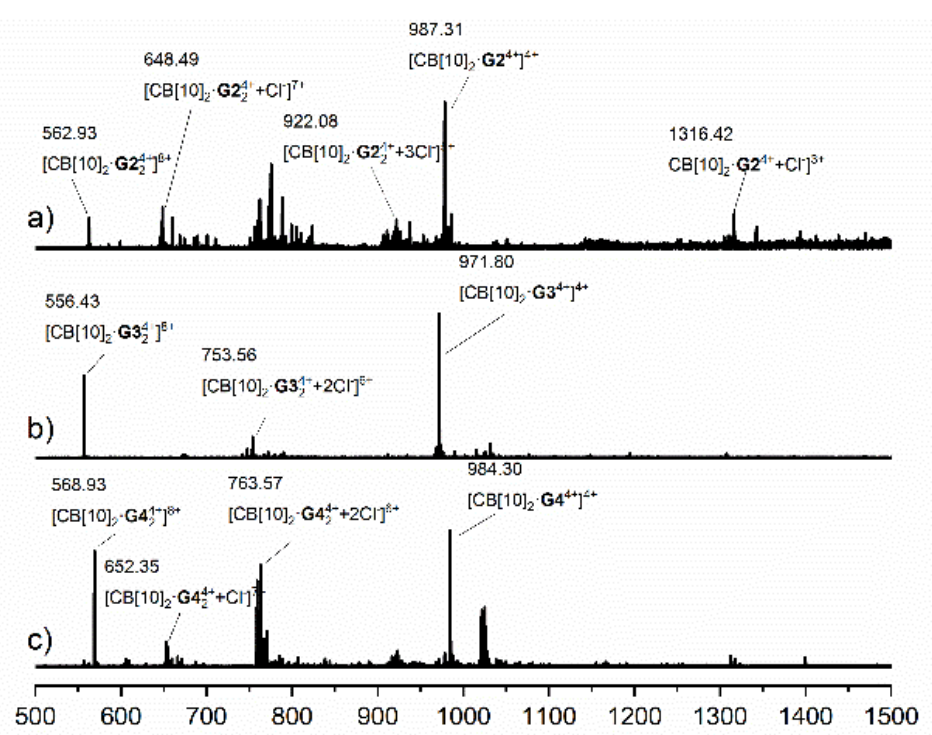

Figure S11. ESI-MS spectra of compound G2 (a), G3 (b), G4 (c) with excess CB[10]: the ion at $m / z=987.31$ corresponds to the $2: 1$ complex $\left(\left[2 \mathrm{CB}[10]+\mathbf{G 2}^{4+}\right]^{4+}=987.25\right)$, ions at $\mathrm{m} / \mathrm{z}=562.93$ and 648.49 correspond to the $2: 2$ complex $\left(\left[2 \mathrm{CB}[10]+2 \mathbf{G 2}^{4+}\right]^{8+}=562.90\right.$; $\left[2 \mathrm{CB}[10]+2 \mathbf{G 2}^{4+}+\mathrm{Cl}^{-7+}=648.38\right)$; the ion at $\mathrm{m} / \mathrm{z}=$ 971.80 corresponds to the $2: 1$ complex $\left(\left[2 \mathrm{CB}[10]+\mathbf{G}^{4+}\right]^{4+}=971.75\right)$, ions at $\mathrm{m} / \mathrm{z}=556.43$ and 753.56 correspond to the $2: 2$ complex $\left(\left[2 \mathrm{CB}[10]+2 \mathrm{G3}^{4+}\right]^{8+}=556.40,\left[2 \mathrm{CB}[10]+2 \mathrm{G}^{4+}+2 \mathrm{Cl}^{-}\right]^{6+}=753.68\right)$; the ion at $\mathrm{m} / \mathrm{z}=984.30$ corresponds to the $2: 1$ complex $\left(\left[2 \mathrm{CB}[10]+\mathbf{G} 4^{4+}\right]^{4+}=984.25\right)$, ions at $\mathrm{m} / \mathrm{z}=568.93$ and 763.57 correspond to the $2: 2$ complex $\left(\left[2 \mathrm{CB}[10]+2 \mathbf{G} 4^{4+}\right]^{8+}=568.90,\left[2 \mathrm{CB}[10]+2 \mathbf{G} 4^{4+}+2 \mathrm{Cl}^{-6+}\right]^{6+763.69}\right)$.

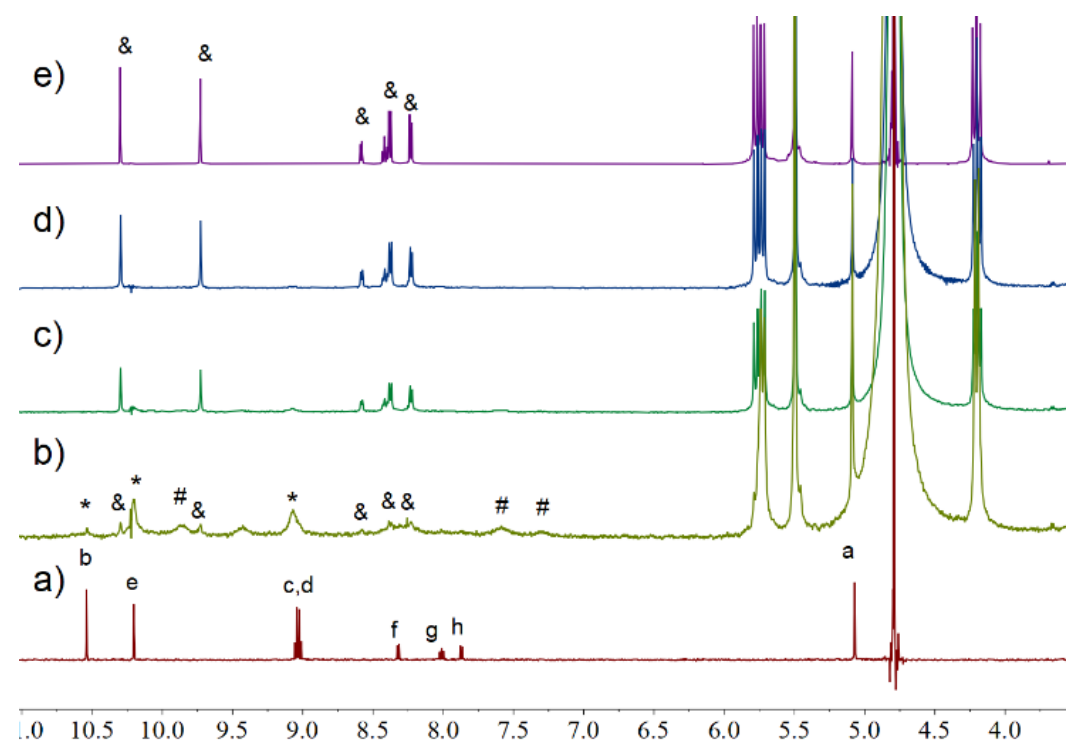

Figure S12. ${ }^{1} \mathrm{H}$ NMR spectra recorded $\left(600 \mathrm{MHz}, \mathrm{D}_{2} \mathrm{O}, 298 \mathrm{~K}\right)$ for compound $\mathbf{G} 3(1.0 \mathrm{mM})$ with different equiv. of $\mathrm{CB}[8]$ (a: 0, b: 1.0, c: 1.4, d: 1.6, e: 2.0) (resonances of free $\mathbf{G} 3$ are marked with '*'; resonances of CB[8] •G3 are marked with '\#', resonances of $\mathrm{CB}[8]_{2} \cdot \mathbf{G} 3$ are marked with ' $\&$ '). 


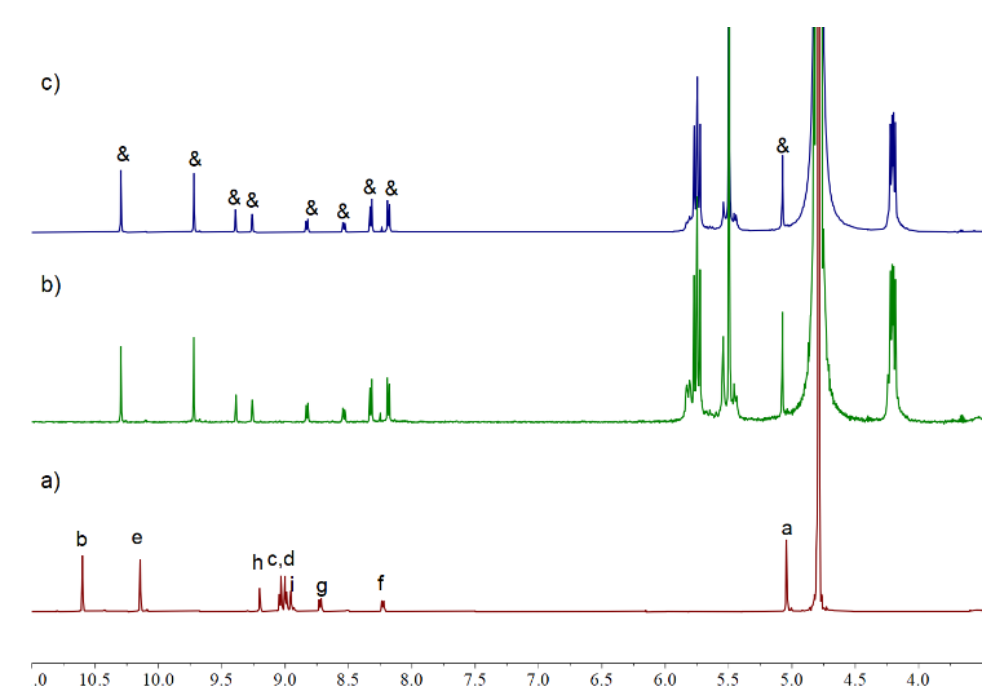

Figure S13. ${ }^{1} \mathrm{H}$ NMR spectra recorded $\left(600 \mathrm{MHz}, \mathrm{D}_{2} \mathrm{O}, 298 \mathrm{~K}\right)$ for compound $\mathbf{G} 4(1.0 \mathrm{mM})$ with different equiv. of $\mathrm{CB}[8]$ (a: $0, \mathrm{~b}: 1.0, \mathrm{c:} 2.0$ ) (resonances of $\mathrm{CB}[8]_{2} \cdot \mathrm{G} 4$ are marked with ' $\&$ ').

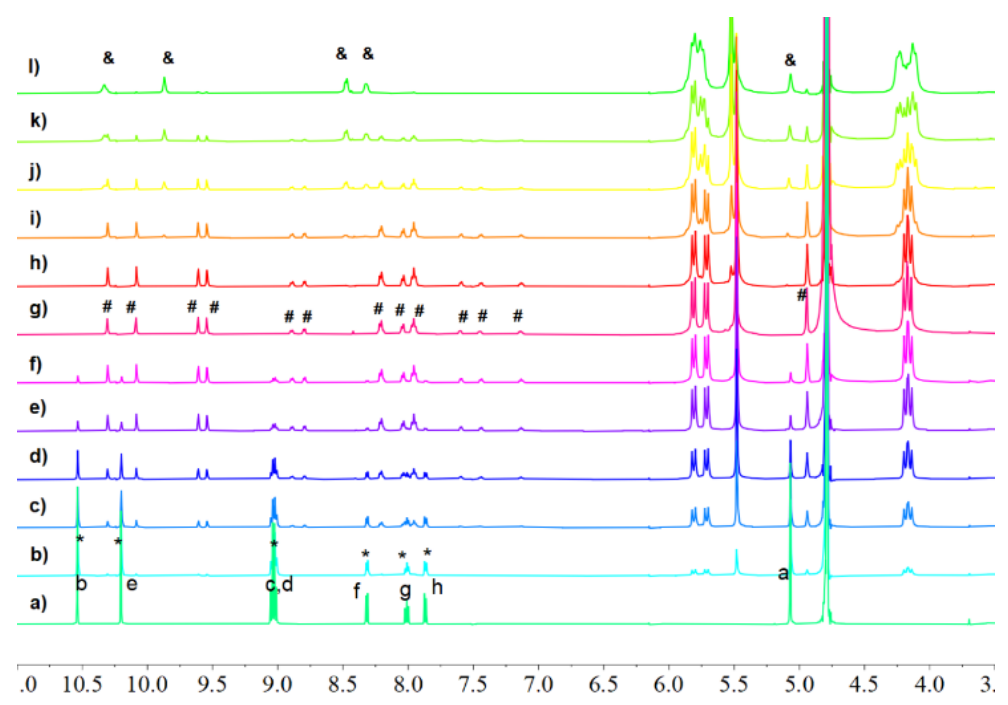

Figure S14. ${ }^{1} \mathrm{H}$ NMR spectra recorded $\left(600 \mathrm{MHz}, \mathrm{D}_{2} \mathrm{O}, 298 \mathrm{~K}\right)$ for $\mathrm{G} 3(1.0 \mathrm{mM})$ with different equivalences of CB[10] (a: 0, b: 0.18, c: 0.36, d: 0.55, e: 0.73, f: 0.91, g: 1.00, h: 1.10, i: 1.27, j: 1.45, k: 1.63, l: 1.82).

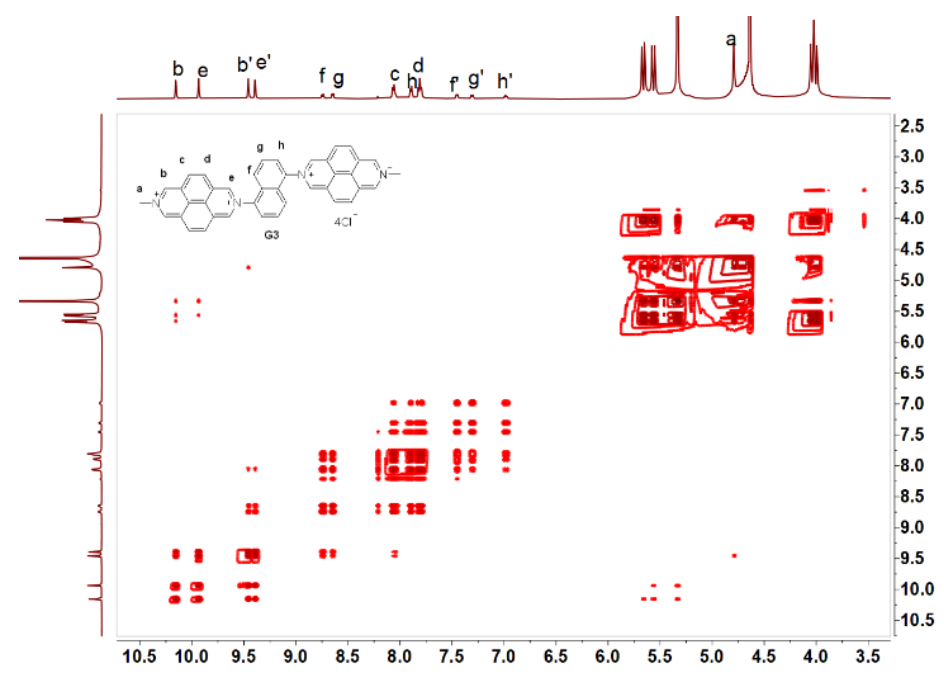

Figure S15. COSY NMR spectrum recorded $\left(600 \mathrm{MHz}, \mathrm{D}_{2} \mathrm{O}, 298 \mathrm{~K}\right)$ for $\mathrm{CB}[10]_{2} \cdot \mathrm{G}_{2}(1.0 \mathrm{mM})$. 


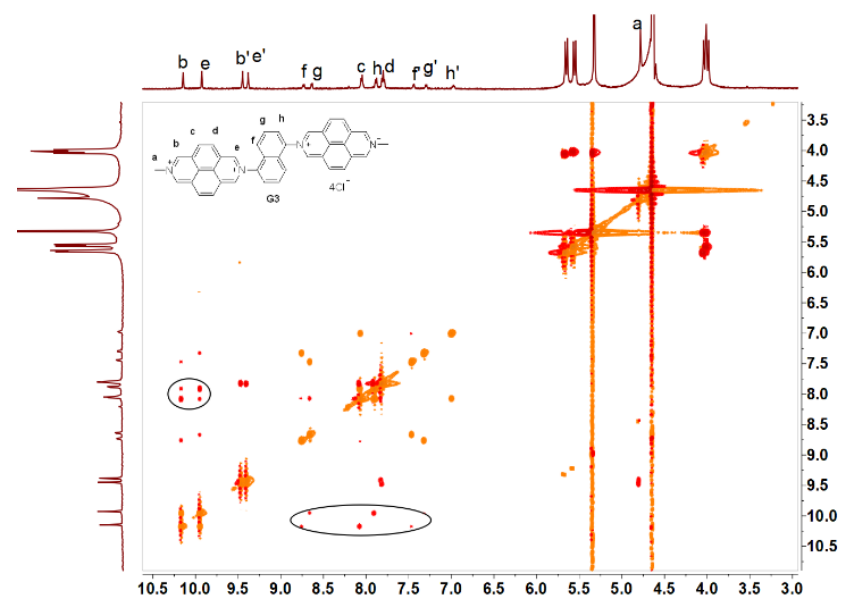

Figure S16. ROESY NMR spectrum recorded $\left(600 \mathrm{MHz}, \mathrm{D}_{2} \mathrm{O}, 298 \mathrm{~K}\right)$ for $\mathrm{CB}[10]_{2} \cdot \mathrm{G}_{2}(1.0 \mathrm{mM})$.

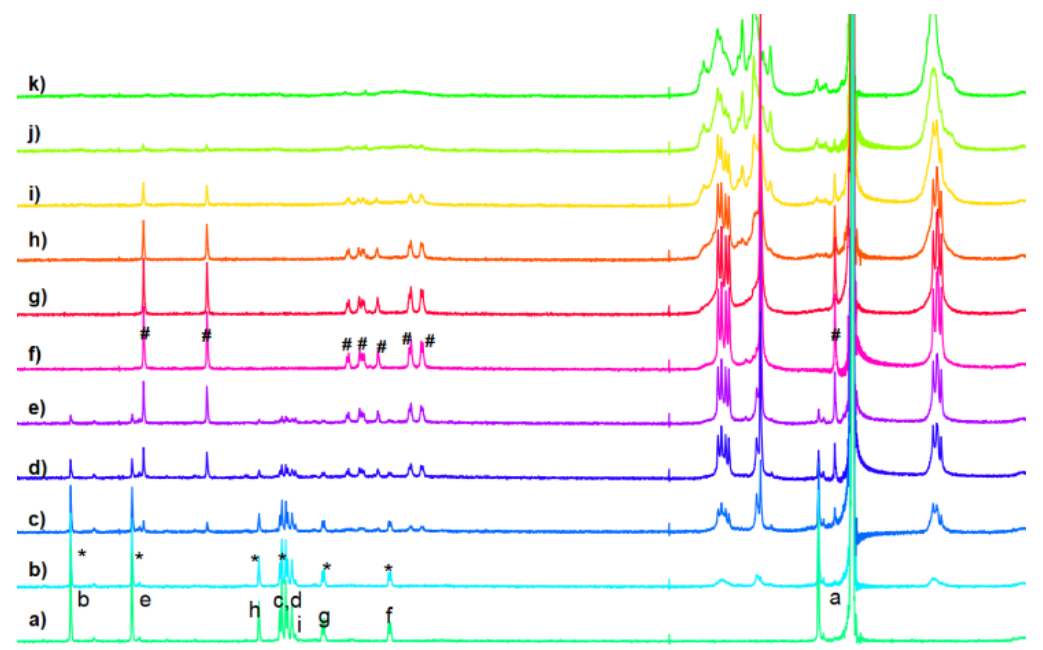

\begin{tabular}{llllllllllllllll}
\hline .0 & 10.5 & 10.0 & 9.5 & 9.0 & 8.5 & 8.0 & 7.5 & 7.0 & 6.5 & 6.0 & 5.5 & 5.0 & 4.5 & 4.0 & 3.
\end{tabular}

Figure S17. ${ }^{1} \mathrm{H}$ NMR spectra recorded $\left(600 \mathrm{MHz}, \mathrm{D}_{2} \mathrm{O}, 298 \mathrm{~K}\right)$ for $\mathbf{G} 4(1.0 \mathrm{mM})$ with different equiv. of $\mathrm{CB}[10]$ (a: 0, b: 0.2 , c: 0.4 , d: 0.6 , e: $0.8, \mathrm{f}: 1.0, \mathrm{~g}: 1.2$, h: $1.4, \mathrm{i}: 1.6, \mathrm{j}: 1.8, \mathrm{k}: 2.0$ ).

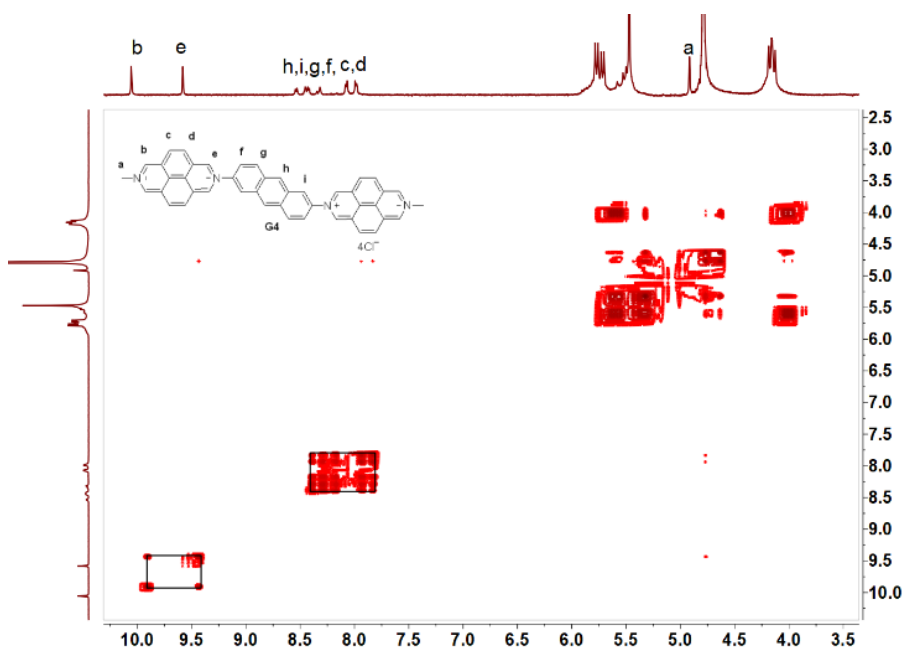

Figure S18. COSY NMR spectrum recorded $\left(600 \mathrm{MHz}, \mathrm{D}_{2} \mathrm{O}, 298 \mathrm{~K}\right)$ for $\mathrm{CB}[10]_{2} \cdot \mathrm{G}_{2}(1.0 \mathrm{mM})$. 


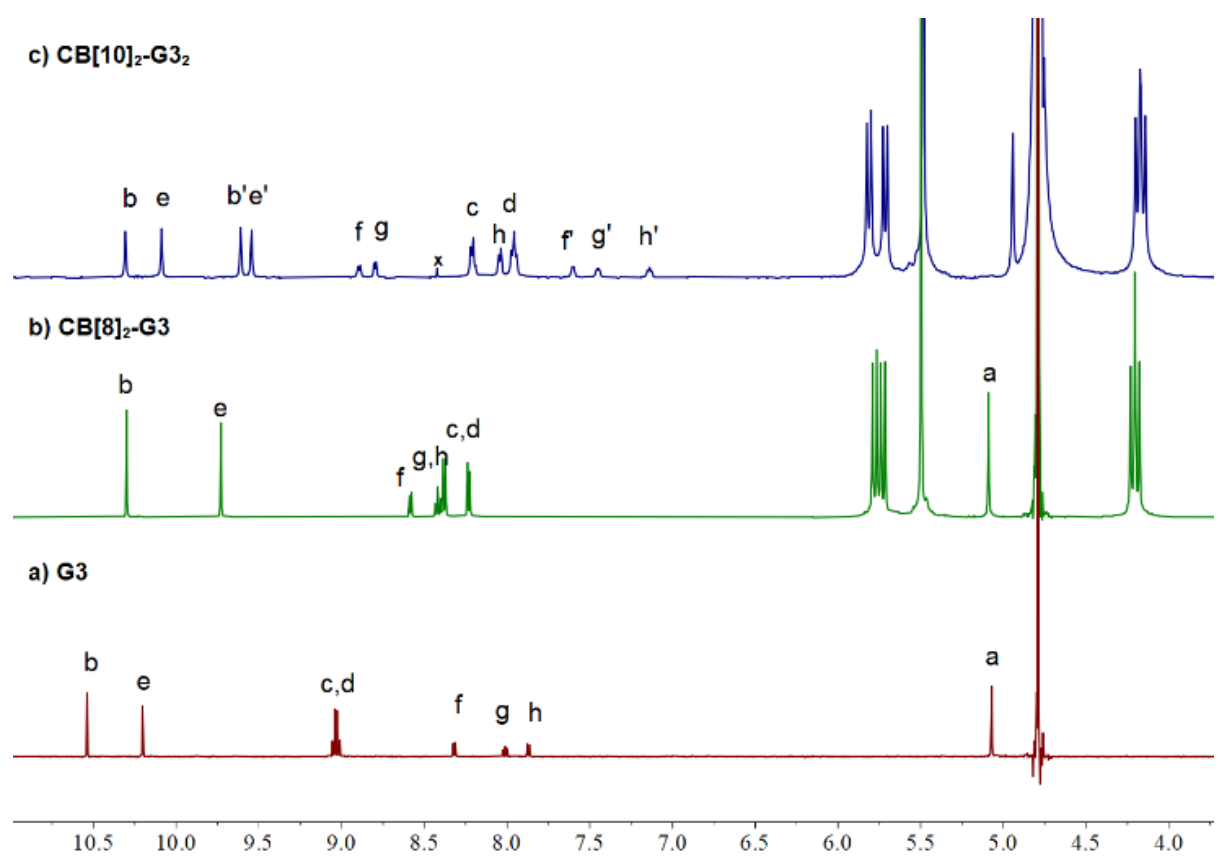

Figure S19. ${ }^{1} \mathrm{H}$ NMR spectra recorded $\left(600 \mathrm{MHz}, \mathrm{D}_{2} \mathrm{O}, 298 \mathrm{~K}\right)$ for compound $\mathbf{G} 3$ (1.0 mM) (a) with $\mathrm{CB}[8]$ (b) and $\mathrm{CB}[10](\mathrm{c})$.

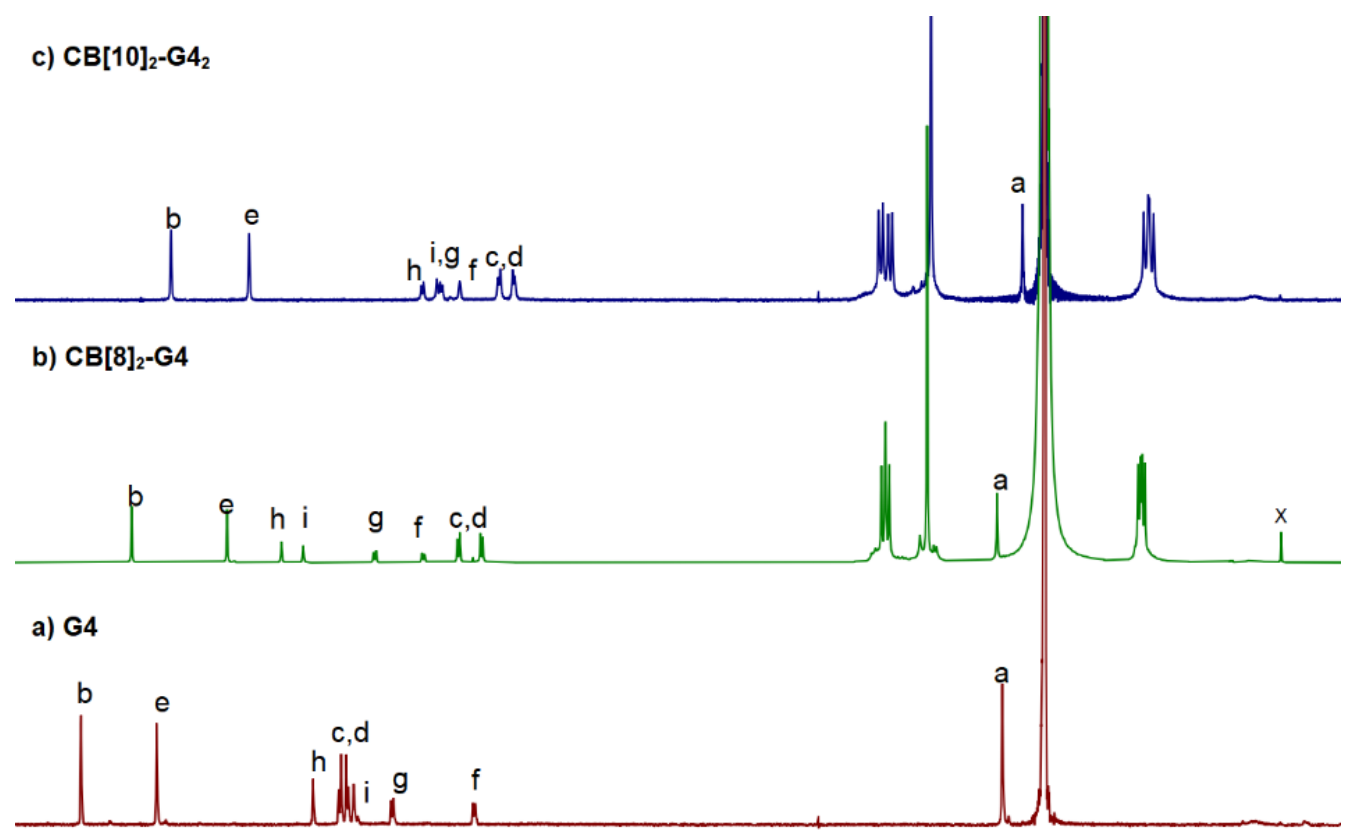

\begin{tabular}{lllllllllllllllllll}
\hline 0 & 10.5 & 10.0 & 9.5 & 9.0 & 8.5 & 8.0 & 7.5 & 7.0 & 6.5 & 6.0 & 5.5 & 5.0 & 4.5 & 4.0 & 3.5 & 3.
\end{tabular}

Figure S20. ${ }^{1} \mathrm{H}$ NMR spectra recorded $\left(600 \mathrm{MHz}, \mathrm{D}_{2} \mathrm{O}, 298 \mathrm{~K}\right)$ for compound $\mathbf{G 4}(1.0 \mathrm{mM})(\mathrm{a})$ with $\mathrm{CB}[8]$ (b) and $\mathrm{CB}[10]$ (c). 
a)

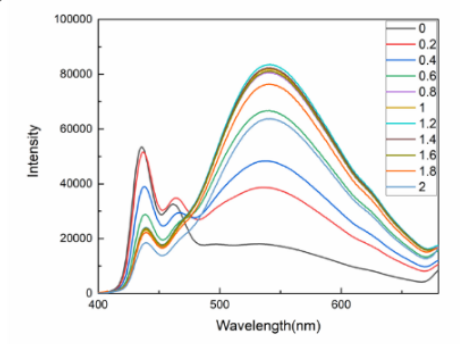

b)

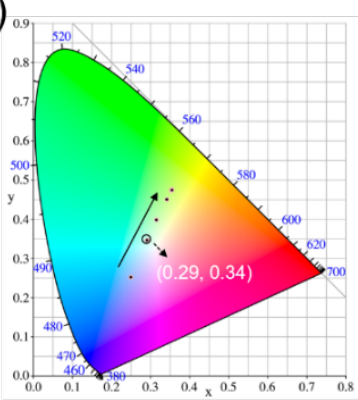

c)

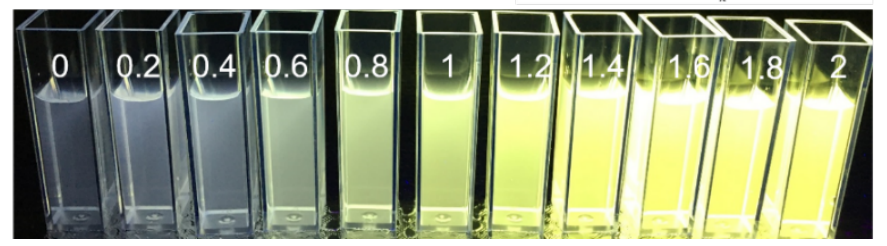

Figure S21. Fluorescence spectra (a) $\left(\lambda_{\mathrm{ex}}=341 \mathrm{~nm}\right.$; slit width: $\left.e_{\mathrm{x}}=5 \mathrm{~nm}, \mathrm{e}_{\mathrm{m}}=5 \mathrm{~nm}\right)$, corresponding $1931 \mathrm{CIE}$ coordinate diagram (b), and fluorescence photographs (c) (under $365 \mathrm{~nm}$ ) of $\mathbf{G} 2(20 \mu \mathrm{M})$ with addition of different equiv. of $\mathrm{CB}[8]$ in water.

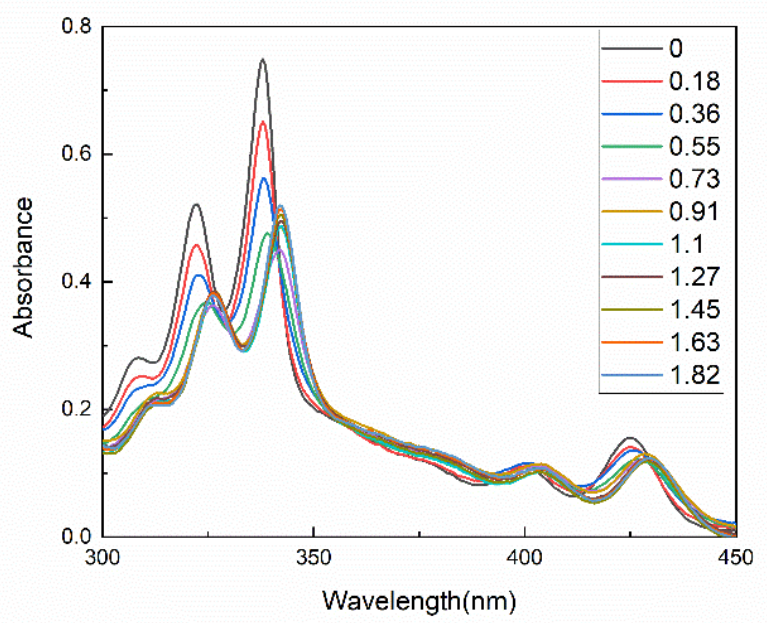

Figure S22. UV-Vis absorption spectra of $\mathbf{G 2}(20 \mu \mathrm{M})$ with addition of different equiv. of CB[10].

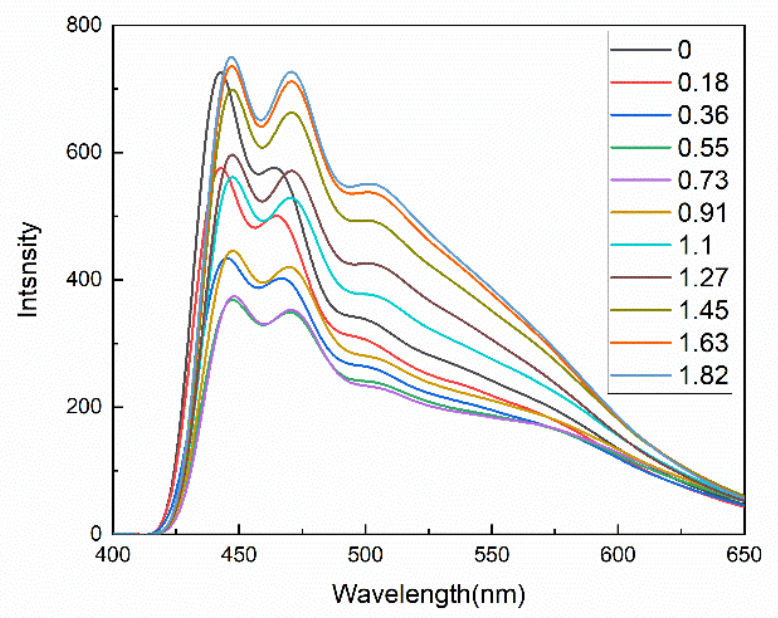

Figure S23. Fluorescence spectra of $\mathbf{G 2}(20 \mu \mathrm{M})$ with addition of different equiv. of CB[10] in water $\left(\lambda_{\mathrm{ex}}=341\right.$ nm; slit width: $\left.e_{x}=15 \mathrm{~nm}, e_{m}=5 \mathrm{~nm}\right)$. 


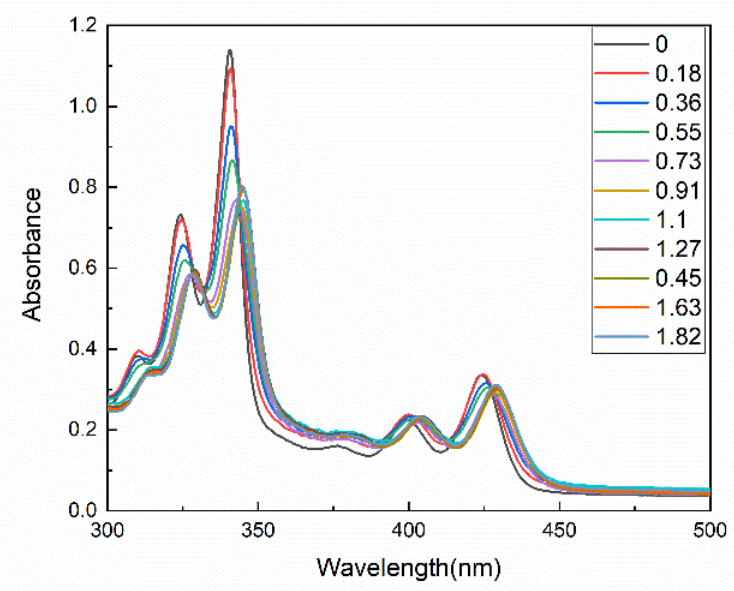

Figure S24. UV-Vis absorption spectra of G3 $(20 \mu \mathrm{M})$ with addition of different equiv. of CB[10].

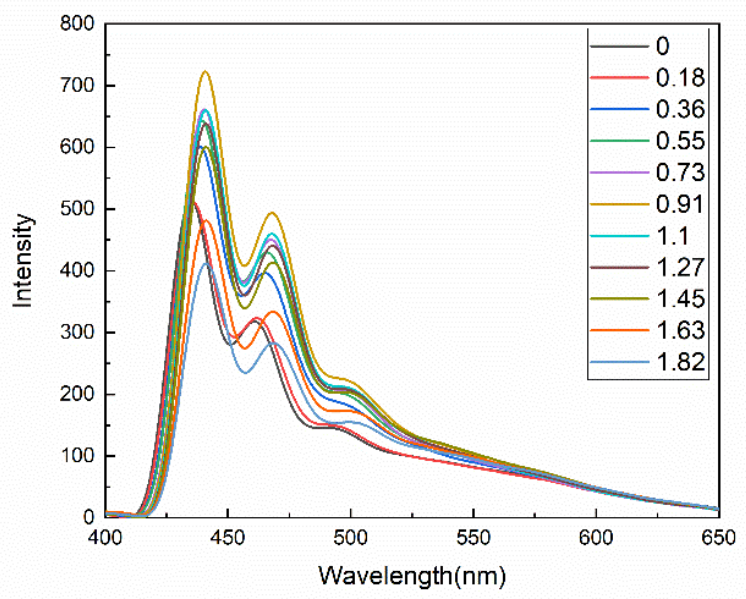

Figure S25. Fluorescence spectra of G3 $(20 \mu \mathrm{M})$ with addition of different equiv. of CB[10] in water $\left(\lambda_{\mathrm{ex}}=341\right.$ $\mathrm{nm}$; slit width: $\mathrm{e}_{\mathrm{x}}=10 \mathrm{~nm}, \mathrm{e}_{\mathrm{m}}=5 \mathrm{~nm}$ ).

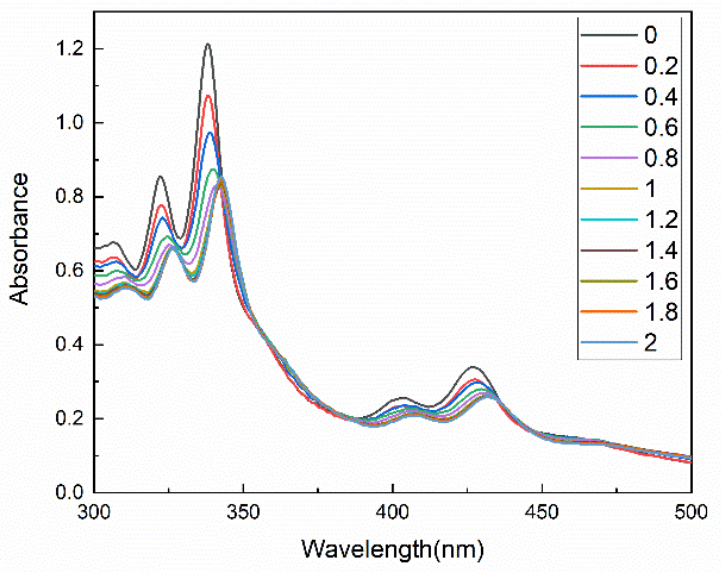

Figure S26. UV-Vis absorption spectra of G4 $(50 \mu \mathrm{M})$ with addition of different equiv. of CB[10]. 


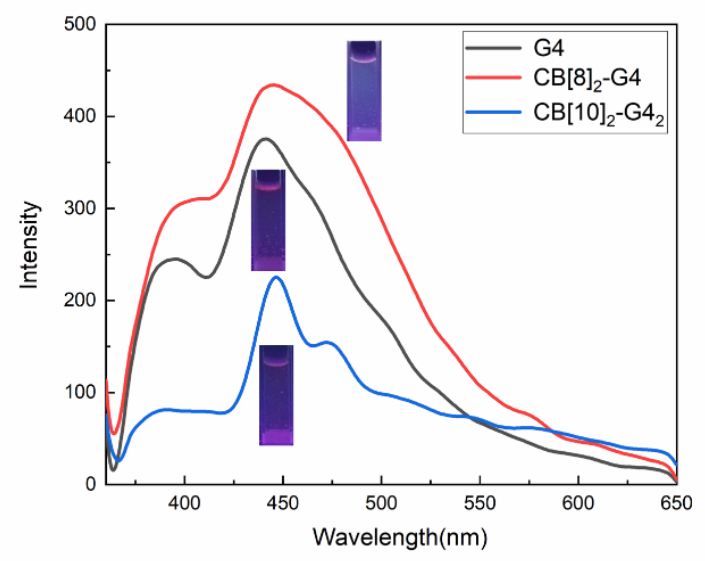

Figure S27. Fluorescence spectra $\left(\lambda_{\mathrm{ex}}=341 \mathrm{~nm}\right.$; slit width: $\left.e_{\mathrm{x}}=5 \mathrm{~nm}, \mathrm{e}_{\mathrm{m}}=5 \mathrm{~nm}\right)$, and fluorescence photographs (under $365 \mathrm{~nm}$ ) of $\mathbf{G} 4(20 \mu \mathrm{M})$ with $\mathrm{CB}[8]$ and $\mathrm{CB}[10]$ in water.

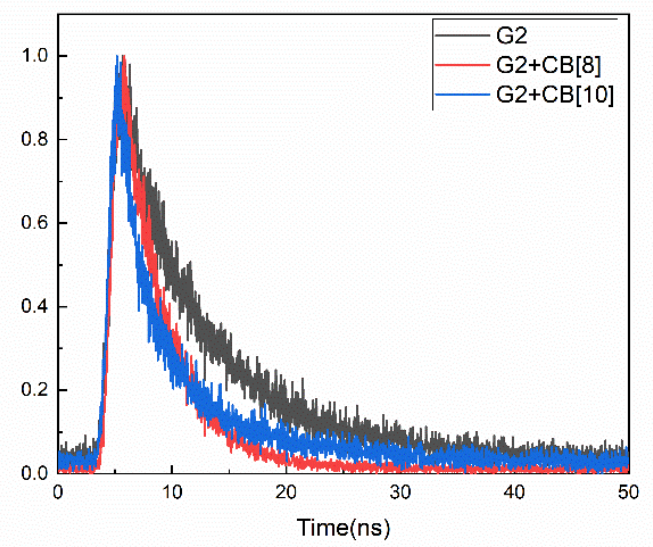

Figure S28. Time-correlated single photon counting decay profiles for $\mathbf{G} 2$ with $\mathrm{CB}[8]$ and $\mathrm{CB}[10]$.

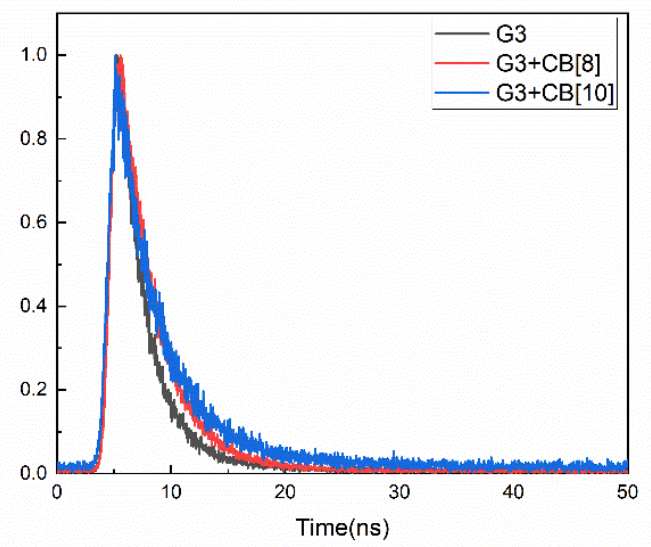

Figure S29. Time-correlated single photon counting decay profiles for $\mathbf{G} 3$ with $\mathrm{CB}[8]$ and $\mathrm{CB}[10]$. 


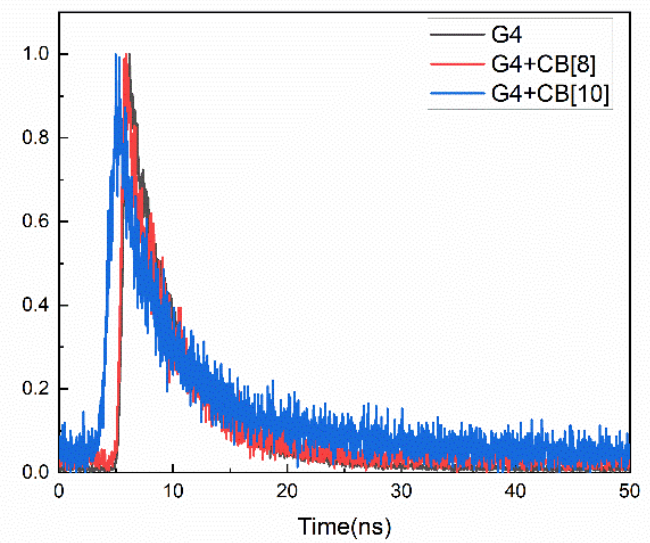

Figure S30. Time-correlated single photon counting decay profiles for $\mathbf{G} 4$ with $\mathrm{CB}[8]$ and $\mathrm{CB}[10]$.

Table S1 Steady-state spectral data of G2-G4 in water.

\begin{tabular}{|c|c|c|c|c|c|c|c|c|}
\hline Guest & Host & $\lambda_{\mathrm{abs}} / \mathrm{nm}$ & $\lambda_{\mathrm{em}} / \mathrm{nm}$ & $\Delta \mathrm{\Lambda} / \mathrm{nm}$ & $\varphi_{\mathrm{F}}$ & $T_{\mathrm{s}} / \mathrm{ns}$ & $k_{\mathrm{nr}} / \mu \mathrm{s}^{-1}$ & $k_{\mathrm{r}} / \mu \mathrm{s}^{-1}$ \\
\hline G2 & - & 337 & 439 & 102 & 0.027 & 7.44 & 130.8 & 3.6 \\
\hline G2 & $\mathrm{CB}[8]$ & 340 & 531 & 191 & 0.175 & 3.84 & 214.8 & 45.6 \\
\hline \multirow[t]{2}{*}{ G2 } & $\mathrm{CB}[10]$ & 342 & 447 & 105 & 0.027 & $2.19(32 \%)$ & 151.8 & 4.2 \\
\hline & & & & & & $8.52(67 \%)$ & & \\
\hline \multirow[t]{2}{*}{ G3 } & - & 341 & 435 & 94 & 0.021 & $2.45(90 \%)$ & 300.3 & 6.4 \\
\hline & & & & & & $10.59(10 \%)$ & & \\
\hline G3 & $\mathrm{CB}[8]$ & 343 & 539 & 196 & 0.133 & 3.24 & 267.6 & 41.0 \\
\hline G3 & $\mathrm{CB}[10]$ & 345 & 441 & 96 & 0.017 & 4.01 & 245.2 & 4.2 \\
\hline \multirow[t]{2}{*}{ G4 } & - & 338 & 442 & 104 & 0.008 & $6.87(58 \%)$ & 102.6 & 0.8 \\
\hline & & & & & & $13.53(42 \%)$ & & \\
\hline G4 & $\mathrm{CB}[8]$ & 340 & 444 & 104 & 0.007 & 8.79 & 113.0 & 0.8 \\
\hline G4 & $\mathrm{CB}[10]$ & 342 & 447 & 105 & 0.005 & 5.33 & 186.7 & 0.9 \\
\hline
\end{tabular}

$\Delta \Lambda$ : wavenumber difference between $\lambda_{\mathrm{abs}}$ and $\lambda_{\mathrm{em}}$ ("Stokes shift"); $\tau_{\mathrm{s}}$ : Fluorescence lifetime; $\varphi_{\mathrm{F}}$ : fluorescence quantum yield; Fluorescence radiative rate estimated using the equation $k_{\mathrm{r}}=\varphi_{\mathrm{F}} / T_{\mathrm{s}} . k_{\mathrm{nr}}=\left(1 / T_{\mathrm{s}}\right)-k_{\mathrm{r}}$. 

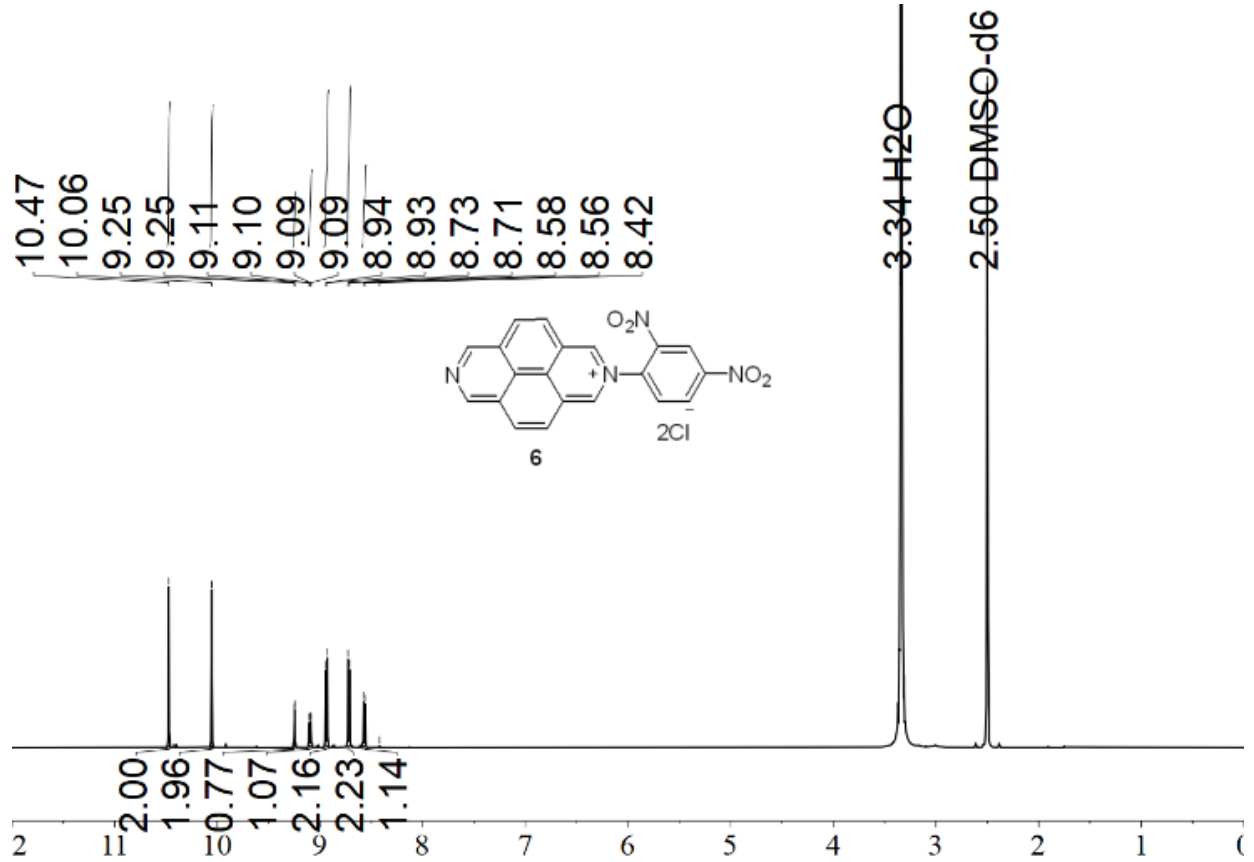

Figure S31. ${ }^{1} \mathrm{H}$ NMR spectrum recorded for compound 6 (600 MHz, DMSO-d $\left.\mathrm{d}_{6}, 298 \mathrm{~K}\right)$.
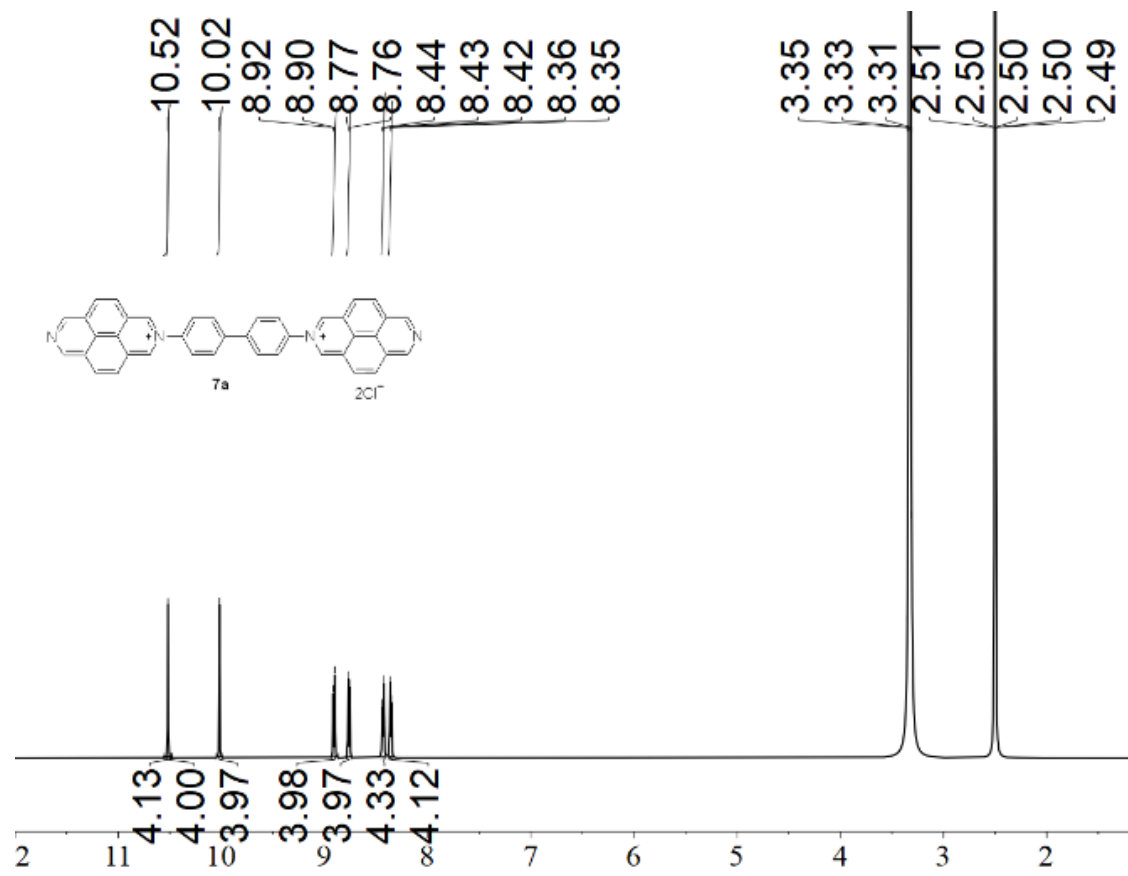

Figure S32. ${ }^{1} \mathrm{H}$ NMR spectrum recorded for compound 7a (600 MHz, DMSO-d 6 , 298K). 


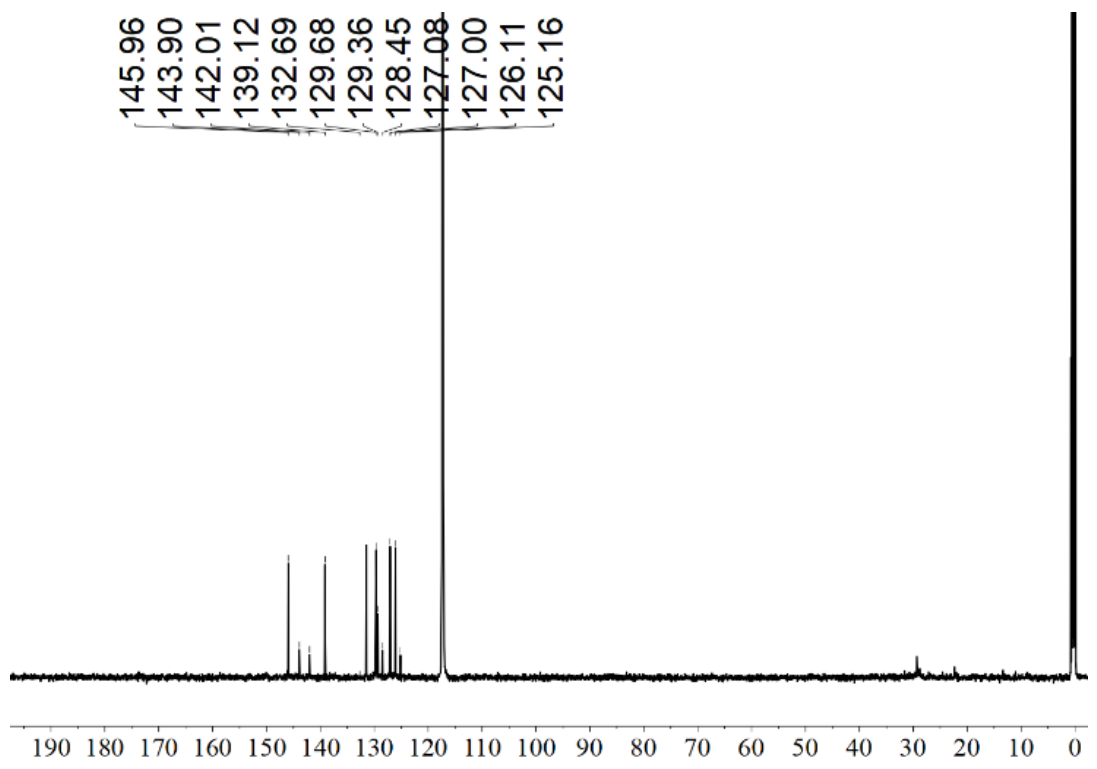

Figure S33. ${ }^{13} \mathrm{C}$ NMR spectrum recorded for compound $7 \mathrm{a}\left(600 \mathrm{MHz}, \mathrm{CD}_{3} \mathrm{CN}, 298 \mathrm{~K}\right)$.

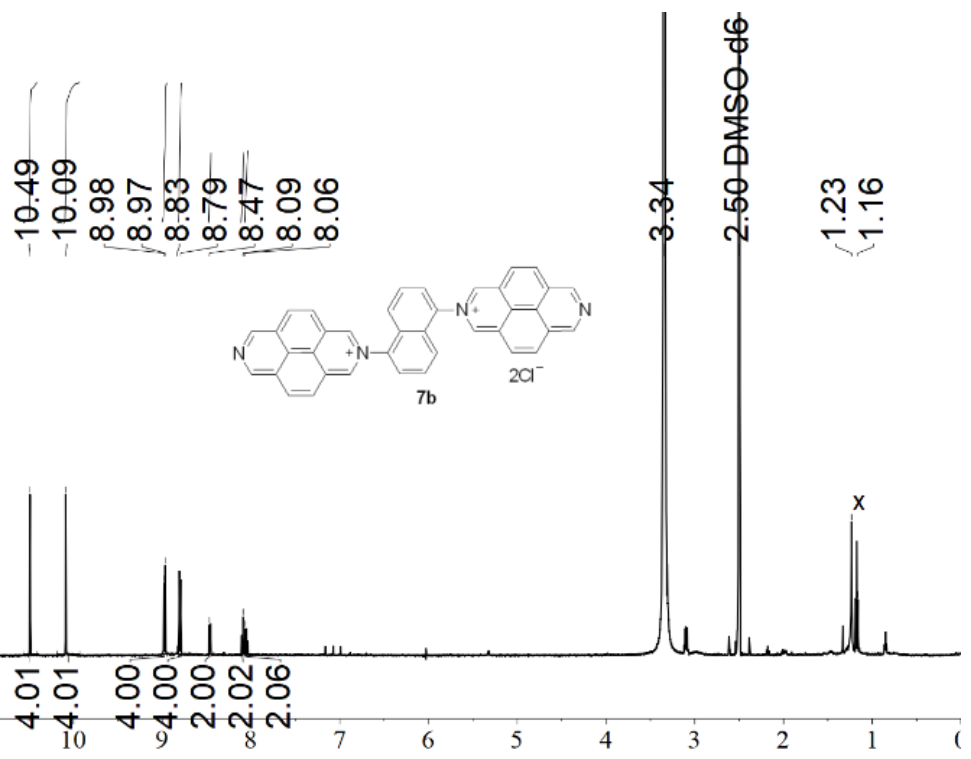

Figure S34. ${ }^{1} \mathrm{H}$ NMR spectrum recorded for compound 7b (600 MHz, DMSO- $\left.\mathrm{d}_{6}, 298 \mathrm{~K}\right)$. 


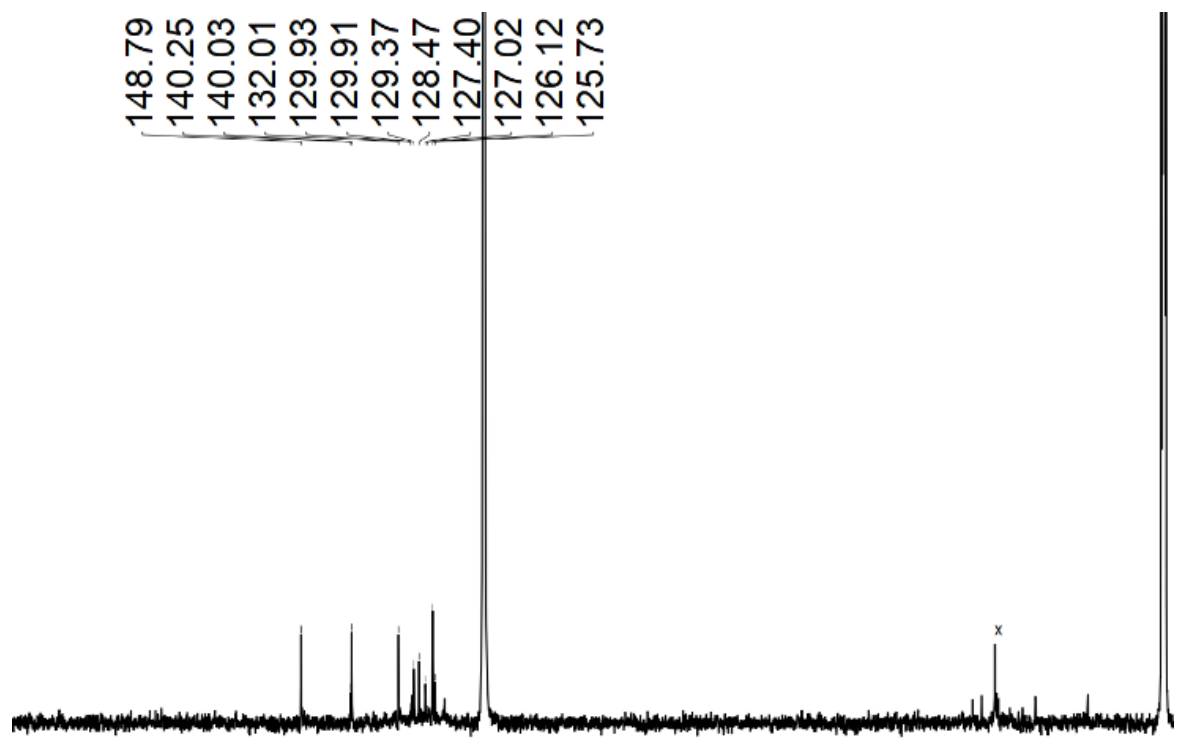

$\begin{array}{llllllllllllllllllllll}190 & 180 & 170 & 160 & 150 & 140 & 130 & 120 & 110 & 100 & 90 & 80 & 70 & 60 & 50 & 40 & 30 & 20 & 10 & 0\end{array}$

Figure S35. ${ }^{13} \mathrm{C}$ NMR spectrum recorded for compound $7 \mathbf{b}\left(600 \mathrm{MHz}, \mathrm{CD}_{3} \mathrm{CN}, 298 \mathrm{~K}\right)$.

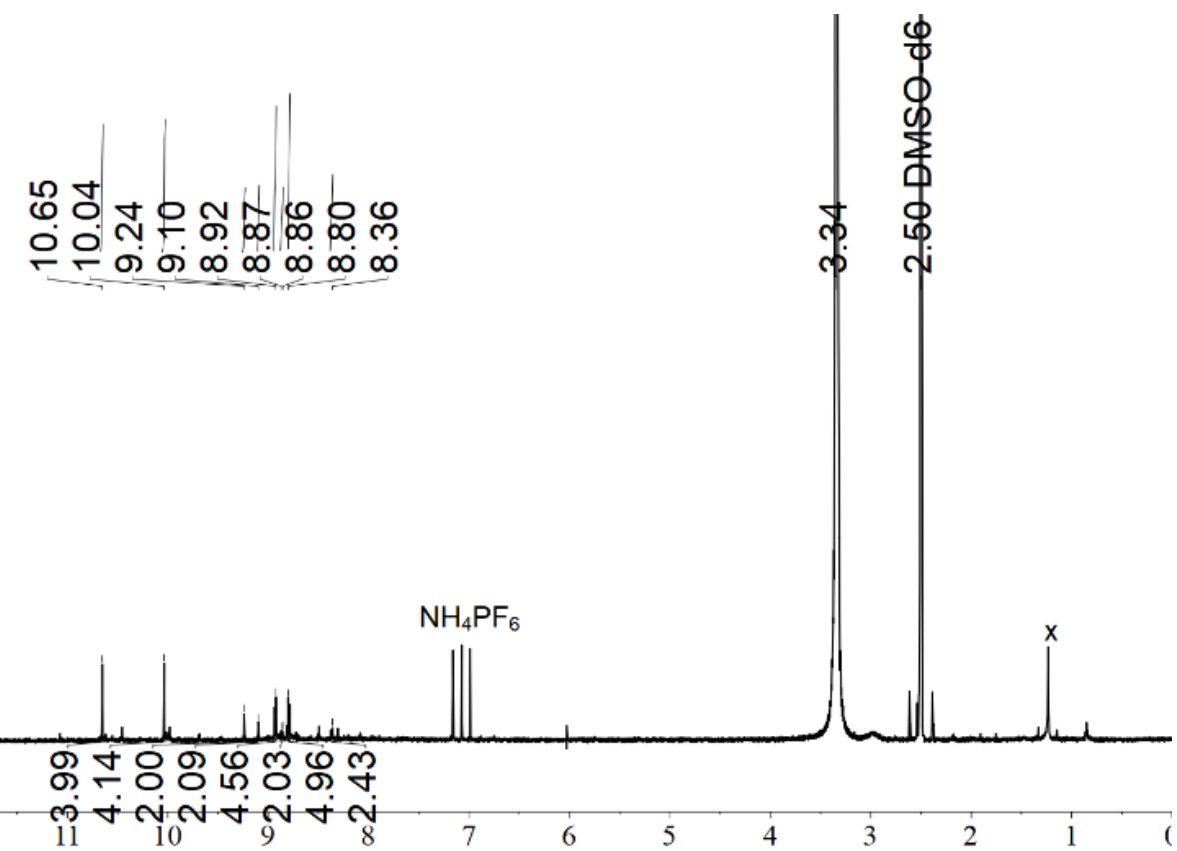

Figure S36. ${ }^{1} \mathrm{H}$ NMR spectrum recorded for compound 7c (600 MHz, DMSO-d 6 , 298K). 


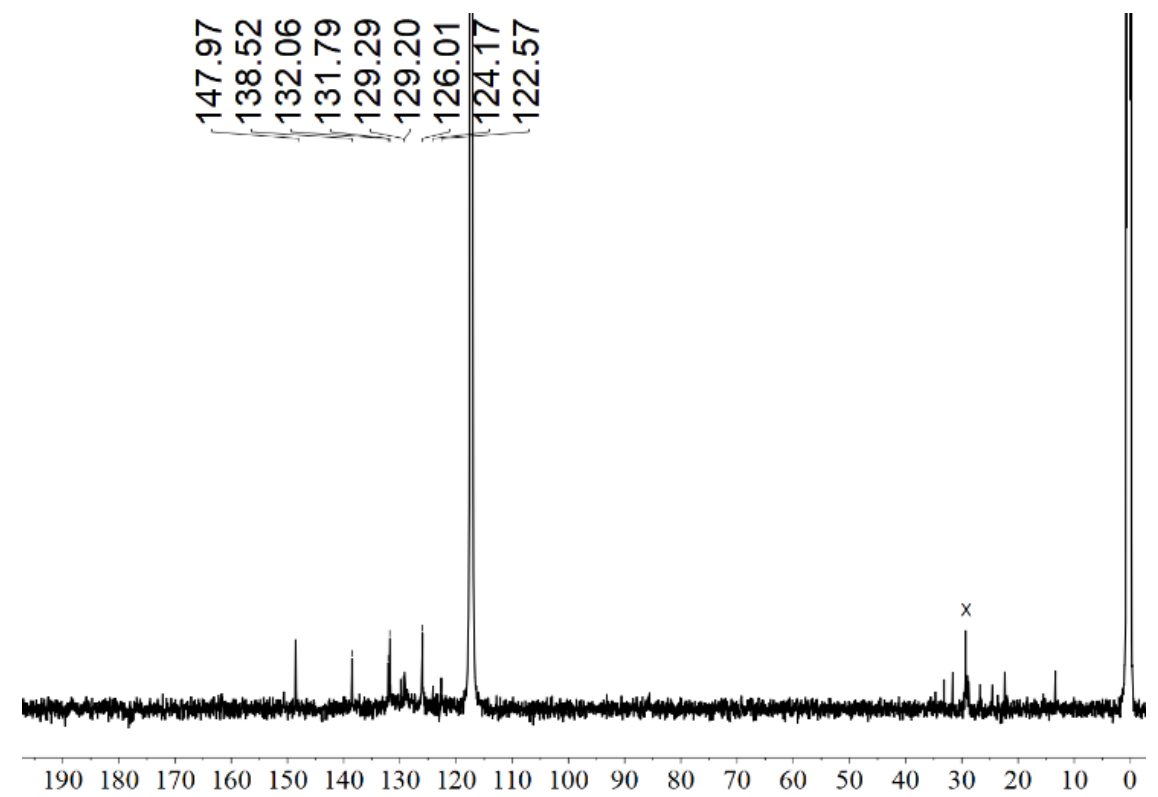

Figure S37. ${ }^{13} \mathrm{C}$ NMR spectrum recorded for compound 7c $\left(600 \mathrm{MHz}, \mathrm{CD}_{3} \mathrm{CN}, 298 \mathrm{~K}\right)$.

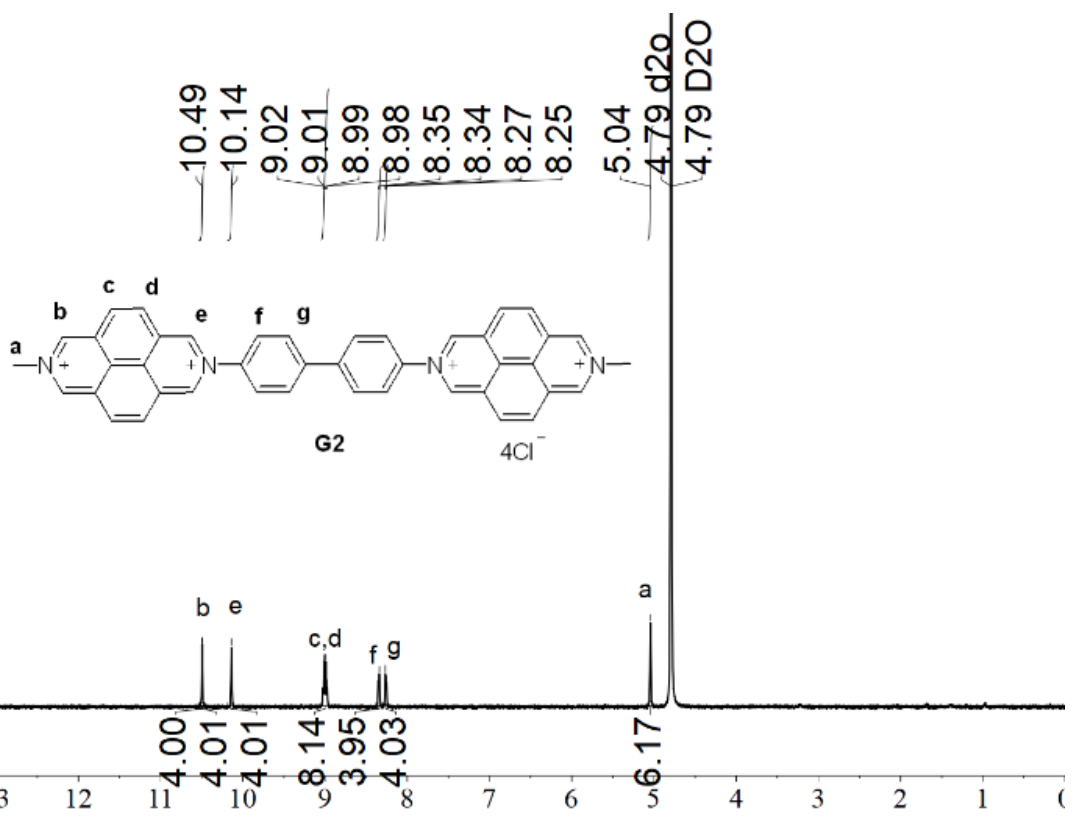

Figure S38. ${ }^{1} \mathrm{H}$ NMR spectrum recorded for compound $\mathbf{G 2}\left(600 \mathrm{MHz}, \mathrm{D}_{2} \mathrm{O}, 298 \mathrm{~K}\right)$. 


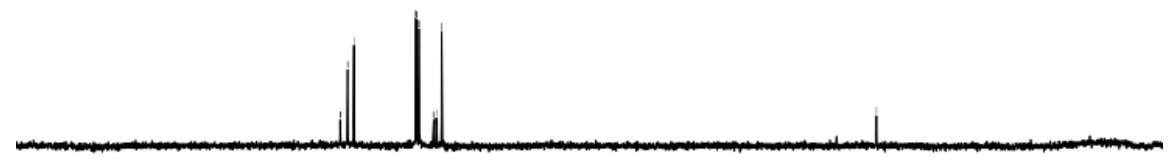

$\begin{array}{lllllllllllllllllllllll}0 & 190 & 180 & 170 & 160 & 150 & 140 & 130 & 120 & 110 & 100 & 90 & 80 & 70 & 60 & 50 & 40 & 30 & 20 & 10 & (\end{array}$

Figure S39. ${ }^{13} \mathrm{C}$ NMR spectrum recorded for compound $\mathbf{G 2}\left(600 \mathrm{MHz}, \mathrm{D}_{2} \mathrm{O}, 298 \mathrm{~K}\right)$.

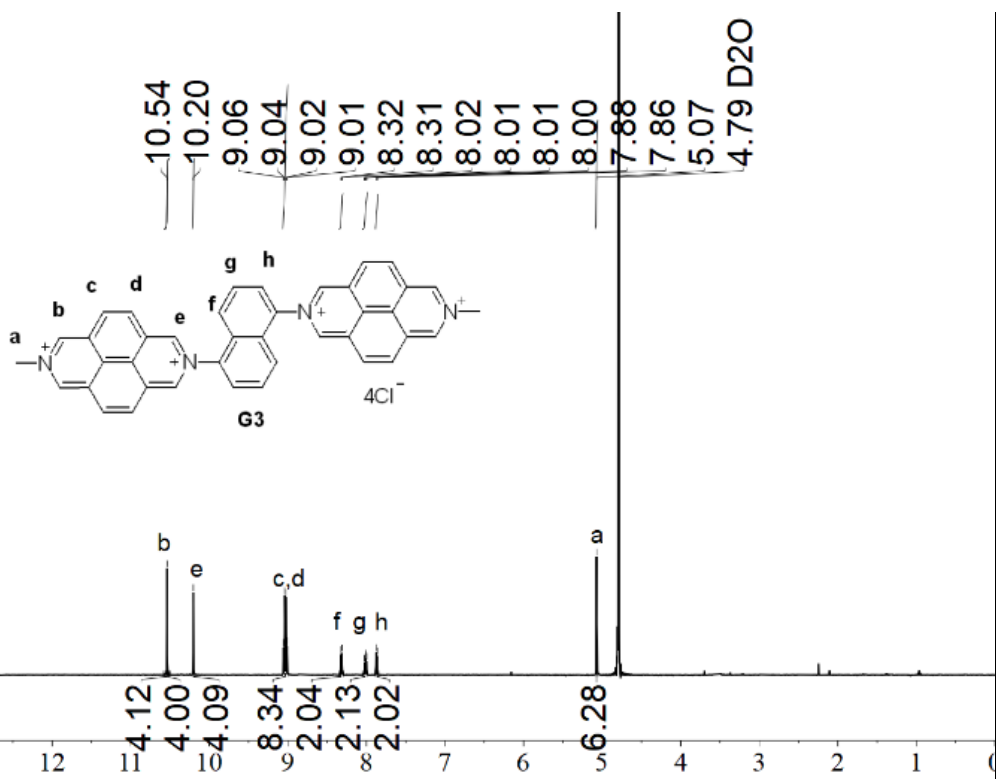

Figure S40. ${ }^{1} \mathrm{H}$ NMR spectrum recorded for compound $\mathbf{G 3}\left(600 \mathrm{MHz}, \mathrm{D}_{2} \mathrm{O}, 298 \mathrm{~K}\right)$. 


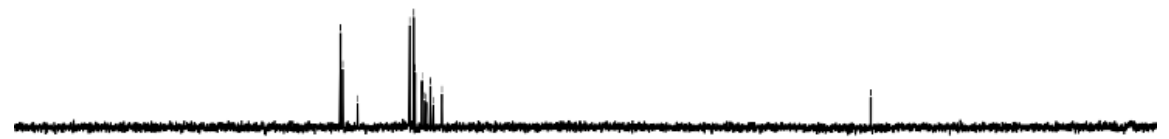

$\begin{array}{llllllllllllllllllllllll}10 & 190 & 180 & 170 & 160 & 150 & 140 & 130 & 120 & 110 & 100 & 90 & 80 & 70 & 60 & 50 & 40 & 30 & 20 & 10 & (\end{array}$

Figure S41. ${ }^{13} \mathrm{C}$ NMR spectrum recorded for compound $\mathbf{G} 3\left(600 \mathrm{MHz}, \mathrm{D}_{2} \mathrm{O}, 298 \mathrm{~K}\right)$.
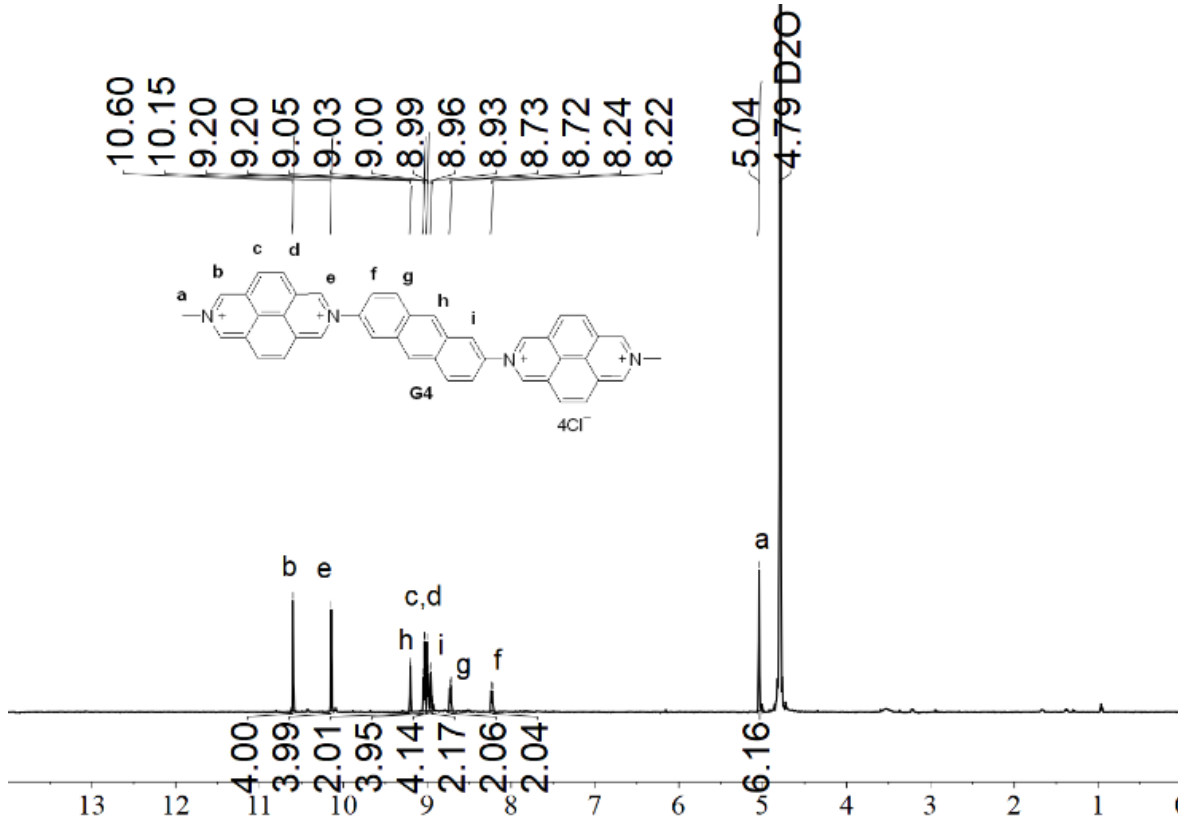

Figure S42. ${ }^{1} \mathrm{H}$ NMR spectrum recorded for compound G4 (600 MHz, $\left.\mathrm{D}_{2} \mathrm{O}, 298 \mathrm{~K}\right)$. 


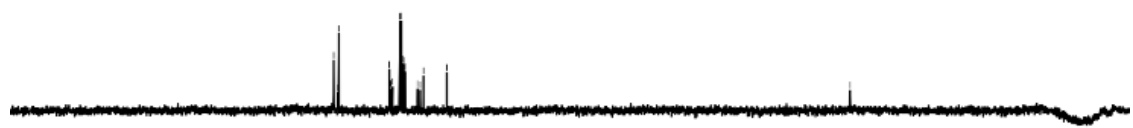

$\begin{array}{lllllllllllllllllllllll}0 & 190 & 180 & 170 & 160 & 150 & 140 & 130 & 120 & 110 & 100 & 90 & 80 & 70 & 60 & 50 & 40 & 30 & 20 & 10 & (\end{array}$

Figure S43. ${ }^{13} \mathrm{C}$ NMR spectrum recorded for compound $\mathbf{G 4}\left(600 \mathrm{MHz}, \mathrm{D}_{2} \mathrm{O}, 298 \mathrm{~K}\right)$.
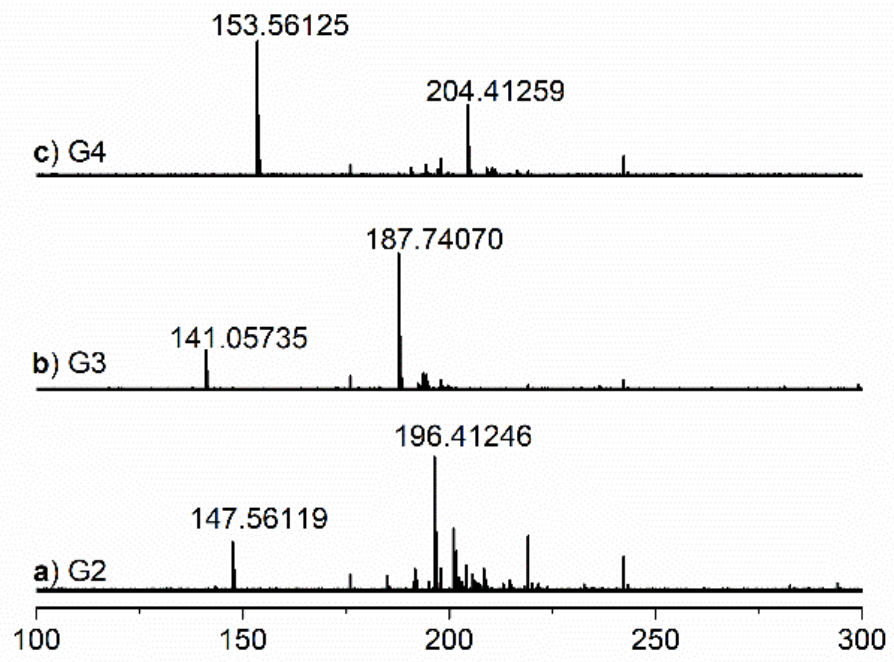

Figure S44. HRMS (ESI) spectra of compound G2 (a), G3 (b), G4 (c).

\section{References:}

1. (a) Day, A.; Arnold, A.P.; Blanch, R.J.; Snushall, B. Controlling factors in the synthesis of cucurbituril and its homologues. J. Org. Chem. 2001, 66, 8094-8100; (b) Yang, X.; Zhao, Z.; Zhang, X.; Liu, S. Probing guest compounds enabling the facile isolation of cucurbit[10]uril. Sci. China Chem. 2018, 61, 787-791.

2. Cejas, M. A.; Raymo, F. M., Fluorescent diazapyrenium films and their response to dopamine. Langmuir 2005, 21, 5795-5802. 